\title{
LOS MOTINES DE 1892 EN CALAHORRA: LA REPERCUSIÓN EN LA PRENSA NACIONAL E INTERNACIONAL DE UN CONFLICTO LOCAL
}

\author{
María Antonia San Felipe Adán \\ Instituto de Estudios Riojanos
}

\begin{abstract}
RESUMEN: Se expone en este artículo los acontecimientos que tuvieron lugar en la ciudad de Calahorra, cabecera de la antigua diócesis de Calahorra-La Calzada conocidos como los motines de junio y julio de 1892 que surgen inicialmente como protesta por el traslado de la Silla episcopal a la capital de la provincia, Logroño en aplicación del Concordato de 1851. La figura de Sagasta defenderá los intereses de Logroño y el cardenal Cascajares a Calahorra. Lo que parecía un conflicto religioso se conviertió en un conflicto político y social de tal envergadura que impregna la prensa nacional e internacional en una España inmersa en un período de inestabilidad y decepción por el sistema político de la Restauración.
\end{abstract}

Palabras clave: Calahorra, motín, 1892, silla episcopal, Sagasta, Cascajares, decepción, Restauración.

ABSTRACT: This article presents the events that took place in the town of Calahorra, the head of the former diocese Calahorra-La Calzada, known as the riots of June and July 1892. Initially, they arose as a protest against the transfer of the bishop's throne to the provincial capital, Logroño, to implement the concordat of 1851. The figure of Sagasta defended the interests of Logroño whereas cardinal Cascajares did so for Calahorra. The religious-like conflict became a political and social clash of such importance that seeped through the national and international press in a period of instability and disappointment in Spain caused by the political system of the Restoration.

Keywords: Calahorra, riot, 1892, bishop's thore, Sagasta, Cascajares, disappointment, Restoration. 


\section{Los orígenes de un conflicto político-religioso generado por el Concordato de 1851}

La aproximación a hechos concretos y el interés por comprenderlos arroja siempre luces y matices sobre la época en que se desarrollaron y nos ayuda a profundizar en los grandes parámetros que enmarcan nuestra historia reciente. Digamos que algo así acontece al estudiar los sucesos que ocurrieron en la ciudad de Calahorra, en la antigua provincia de Logroño, en el año de 1892 cuando el siglo XIX se encaminaba a su fin. Trataré de abordar esa realidad social y política del municipio calagurritano para valorar cómo lo acontecido se inserta a la perfección en los avatares de la política nacional, en la prensa de la época y también en su indiscutible proyección internacional. Todavía hoy sorprende que un hecho de índole y causas, aparentemente locales, invadiera la prensa nacional de 1892, fuera motivo de acalorada discusión en el Congreso de los Diputados y cruzara el océano para convertirse en noticia del prestigioso diario The New York Times.

Para comprender mejor esta interesante microhistoria trataremos de explicar lo que pudiéramos denominar los orígenes de los conocidos motines de Calahorra, una ciudad que en 1892 contaba con algo más 9.000 habitantes ${ }^{1}$ y se encontraba en una fase de estancamiento en su crecimiento poblacional y económico pese a contar con una importante industria ligada a la transformación de los productos agrarios. En Calahorra existían en 1890 al menos 38 empresas conserveras de las 64 registradas en toda España, es decir contaba con una economía especializada en ese subsector industrial que se dirigía a satisfacer la demanda interna y a la exportación pero la escasa diversificación económica ligaba el bienestar de la ciudad a los vaivenes de la agricultura y de la propia industria conservera ${ }^{2}$.

Calahorra tiene una peculiaridad que la diferencia de otras ciudades de su tamaño, tanto en la época que estudiamos como en la actualidad, ya que es cabecera de una de las diócesis más antiguas de España, la de Calahorra y La Calzada. Diremos por tanto que los asuntos, cuya trascendencia tratamos de analizar, hunden sus raíces en la aprobación del Concordato de 1851 suscrito entre la Reina de España, Isabel II y la Santa Sede representada por el Papa Pío IX. Dicho acuerdo internacional, fue rubricado el 16 de marzo de $1851^{3}$. El texto acordado proclamaba la unidad católica de España, garantizaba la protec-

1. Según los datos del INE, Censos de Población Calahorra tenía en 1887, 9.525 habitantes de hecho y en 1897, dos más, 9.527.

2. A este respecto es interesante ver López Rodríguez, P., Calahorra, Levítica y Liberal. Cambio socioeconómico y caciquismo liberal en La Rioja Baja, 1890-1923, Amigos de la Historia de Calahorra, 1997.

3. Gaceta de Madrid, no 6.306 de 19 de octubre de 1851, p. 2. El Concordato se publicó el día 19 de octubre de 1851 pero debió ser editado, de nuevo, al día siguiente por haberse omitido la fórmula final de promulgación de la ley. 
ción a la Iglesia y, entre otros aspectos, reorganizaba las delimitaciones de las diócesis bajo nueve arzobispados.

En el caso de la diócesis de Calahorra y La Calzada el Concordato suscrito repercutía en varios aspectos de su organización interna. En primer lugar, se creaba una nueva diócesis, la de Vitoria, que agruparía a todas las provincias vascas y que sería segregada de su diócesis matriz. El otro aspecto no menos importante era la disposición que resolvía la traslación de la Silla episcopal de Calahorra a la capital provincial, Logroño. Ambas instrucciones se encuentran recogidas en el artículo 5 del citado texto legal y será la persistencia en su aplicación la que generará enormes tensiones entre la capital político-administrativa, Logroño y la capital diocesana, Calahorra ${ }^{4}$.

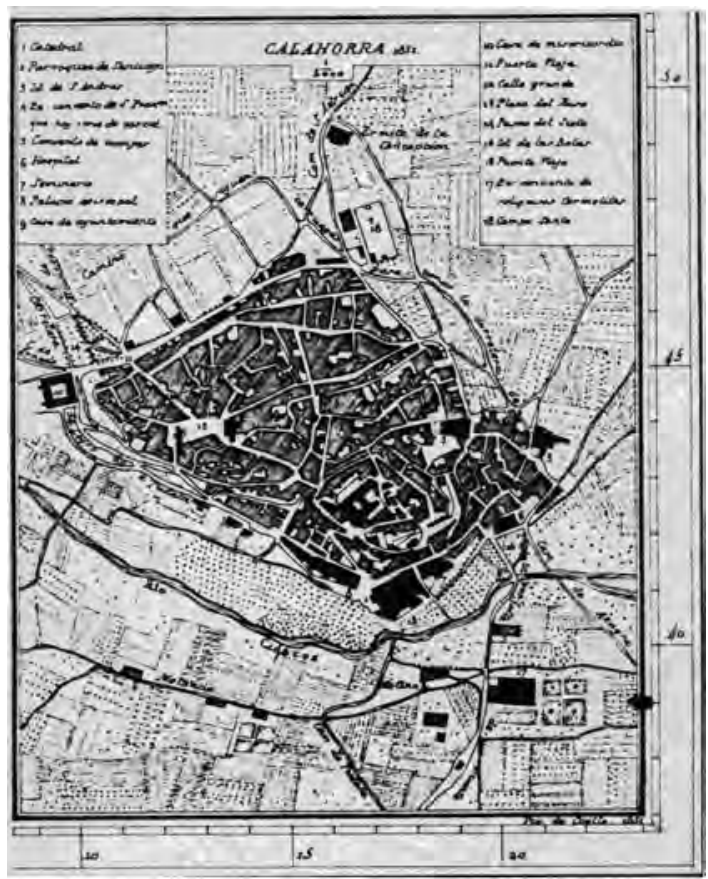

Lám. 1. Calahorra 1851. Mapa de Coello.

4. "Se erigirán nuevas Diócesis sufragáneas en Ciudad Real, Madrid y Vitoria. La Silla episcopal de Calahorra y La Calzada se trasladará a Logroño; la de Orihuela a Alicante, y la de Segorbe a Castellón de La Plana, cuando en estas ciudades se halle todo dispuesto al efecto y se estime oportuno, oídos los respectivos Prelados y Cabildos". Gaceta de Madrid, n 6.306 de 19 de octubre de 1851, p. 2. 
Desde el mismo momento de su firma ese asunto se convertirá en la principal preocupación de los sucesivos obispos de la diócesis de Calahorra y La Calzada. Así Cipriano Juárez y Berzosa, nombrado obispo el 12 de junio de 1852, tuvo que afrontar el desgaste que suponían las órdenes de la propia reina que el 24 de mayo de 1853, le informaba que el arquitecto y académico de la Real de San Fernando, Francisco Enríquez Ferrer, había sido nombrado para visitar las iglesias de La Redonda, Santiago y Palacio, a fin de realizar presupuesto de las obras para la iglesia que se considerase más adecuada pudiera convertirse en Catedral. Éste es el inicio de un largo camino que tenía como finalidad dotar a Logroño de lo necesario para dar cumplimiento a lo previsto en el Concordato y para lo que precisaba de un palacio para el Obispo y de un templo con empaque suficiente para convertirse en la Catedral de la Diócesis 5 .

A Berzosa le sucedió en 1861 Antolín Monescillo y Viso por decreto de la Reina de 19 de mayo $^{6}$. Su nombramiento fue retrasado mientras se iban realizando los preparativos para proceder a la creación de la nueva Diócesis de Vitoria que absorbería parte de la diócesis de Burgos, parte de la de Santander y de la de Calahorra e integraría a las tres provincias vascas ${ }^{7}$. Monescillo impulsó la segregación de la diócesis de Calahorra, algo que no quiso realizar su antecesor y que solamente contó con la oposición del abad de Santo Domingo de La Calzada, Justo Barbagero, que consideraba que la nueva diócesis iba a tener una jurisdicción muy amplia y mucha población llegando a ser mayor que la propia metropolitana de Burgos y además consideraba que cuanta mayor fuera la fuerza de la dependencia eclesiástica de esas provincias más fácil sería mantenerlas fieles "para que nunca piensen en romper de una manera estable con la monarquía española" ${ }^{\prime \prime}$. Por su parte el obispo MonesciIlo dejó claro al ministro de Gracia y Justicia que no pondría ningún obstáculo y que facilitaría en lo que pudiera la segregación pretendida y así el 29 de

5. Archivo Municipal de Logroño (AML), Sig. P1/5.

6. Gaceta de Madrid, no 192 de 11 de julio de 1861.

7. Antolín Monescillo había nacido en Corral de Calatrava (Ciudad Real) el 2 de septiembre de 1811 y falleció en Toledo el 11 de agosto de 1897. Formó parte de las Cortes Constituyentes de 1869, donde destacó como hábil orador parlamentario. Participó activamente en la discusión de la totalidad del proyecto constitucional y es conocida su intervención a favor de la unidad religiosa. Permaneció alejado de la vida política en las sucesivas Cortes como protesta al nuevo régimen constituido. En 1877 fue propuesto por el Gobierno conservador para la archidiócesis de Valencia. En julio de 1892, parece que por indicación de León XIII, fue nombrado arzobispo de Toledo. Entró en esta ciudad en agosto de 1892, en Enciclopedia Universal Ilustrada EuropeoAmericana, Hijos de J. Espasa, Barcelona 1918, Tomo 36, p. 129.

8. Rodríguez del Coro, F., País Vasco, Iglesia y Revolución Liberal, Caja de Ahorros Municipal de la Ciudad de Vitoria, 1978, Apéndice documental, pp. 334-337.

9. Rodríguez del Coro, F., Revolución burguesa e ideología..., p. 31, en AMJ, oficio del obispo Monescillo al ministro Negrete, 11 de abril de 1862, leg. 4027. 
abril de 1862 tomaría posesión de la diócesis de Vitoria su primer obispo Diego Mariano Alguacil y Rodríguez haciendo su entrada triunfal "con las mayores muestras de júbilo y satisfacción de la ciudad de Vitoria y de las tres provincias vascongadas que vieron de esta forma coronados los anhelos de varias generaciones"10.

A sensu contrario la diócesis calagurritana quedó notablemente empobrecida ya que perdió 553 de sus 950 parroquias que se integraban en la nueva diócesis de Vitoria, lo que significaba una pérdida de población del territorio administrado de 255.023 habitantes y los ingresos de la Mitra se redujeron en un $75 \%$, se pasó de 2.228 eclesiásticos, entre párrocos, coadjutores, clero secular y regular, a un total de $904^{11}$.

Sin embargo estos hechos no contaron en la población con ningún tipo de oposición algo muy distinto a lo ocurrido con el intento de trasladar la silla episcopal a Logroño. Durante los años sucesivos la corporación municipal logroñesa iba avanzado en sus preparativos y en sus presiones políticas ante los gobiernos de turno para conseguir que se hiciera realidad el acuerdo suscrito entre el gobierno español y la Santa Sede. Sin embargo el incipiente conflicto permanecía larvado porque ninguno de los obispos sucesivos se atrevía a tomar una posición que determinara la resolución del mismo ya que, para que así ocurriera, era necesario el placet del propio obispo y del Cabildo, algo difícil de conseguir por su residencia en Calahorra o porque en el caso del obispo Fabián Sebastián Arenzana y Magdalena, por ejemplo, que era natural de Calahorra y que fue nombrado en 1865 no tenía disposición favorable a la ejecución del traslado.

Entre las anécdotas que ilustran la complejidad del asunto, cabe destacar el enfrentamiento que durante 1868 protagonizaron las distintas Juntas Revolucionarias de la Rioja y que se plasmó el 19 de octubre cuando en el Boletín Extraordinario de la Provincia, se publicaba un acuerdo de la Junta Revolucionaria de Logroño ordenando la supresión de los Seminarios de Calahorra y Santo Domingo de la Calzada y se disponía el inmediato traslado de las matrículas de los alumnos al seminario de Logroño. La singular disposición revolucionaria no fue adoptada por consideraciones anticlericales sino simplemente porque los junteros consideraban que la creación de ambos seminarios había "lastimado" los intereses legítimos de la capital. No puede obviarse por lo sorprendente que al grito de ¡Viva la libertad!, ¡Abajo los Borbones!, el nuevo poder civil quisiera

10. Pérez Alhama, J., "Estudio histórico jurídico sobre la erección de la diócesis de Vitoria", p. 376, en VV.AA., Obispados de Alava, Guipúzcoa y Vizcaya hasta la erección de la Diócesis de Vitoria, Editorial Eset, Vitoria, 1964.

11. Ochoa Alfaro, Á. J., "El Concordato de 1851 y sus consecuencias en la diócesis de Calahorra y La Calzada", Kalakoricos, no 3, 1998, pp. 169-183. 
suprimir dos instituciones eclesiásticas descentralizadas únicamente para fortalecer al seminario religioso de la capital ${ }^{12}$.

\section{Las tensiones territoriales por la traslación de la Silla Episcopal de la diócesis de Calahorra y La Calzada}

El 5 de julio de 1875 fue nombrado obispo Gabino Catalina del Amo y como cada vez que llegaba un nuevo obispo los rumores sobre la traslación volvían de nuevo a incomodar incomodar a los calagurritanos mientras los logroñeses reiniciaban sus gestiones. El 30 de diciembre de 1876 Logroño vuelve a pedir al Rey el traslado de la silla y alegan, entre otras cuestiones, que en los años que van de 1222 a 1624 había residido en Logroño el obispo de Calahorra y su tribunal. Calahorra, por su parte, mantiene inalterable su postura con una nueva solicitud ante el Rey de fecha 4 de enero de 1877, en la que reitera los argumentos de la antigüedad y tradición de la diócesis y el duro golpe que supondría tal acontecimiento para la ciudad. El 3 de febrero de 1877 el rey Alfonso XII, ante la persistencia del conflicto y la impopularidad con riesgos de enfrentamiento, decidió dilatar sine die la decisión definitiva tras la intermediación del marqués de Orovio que apoyaba las tesis de los calagurritanos ${ }^{13}$.

La muerte del obispo Catalina del Amo el 10 de enero de 1882 fue de nuevo fuente de rumores y de gestiones de los logroñeses ante el valedor de la capital e Hijo Predilecto de la misma, Práxedes Mateo Sagasta. Vacante la silla y mientras se adecuaba la colegiata de la Redonda para convertirla en catedral, Logroño recibía con regocijo la promesa del ministro de Justicia de adquirir un edificio para palacio episcopal. Por su parte, la Corporación logroñesa acordaba, el 17 de marzo de 1883, por unanimidad y con grandes esperanzas, hacerse cargo del importe de su restauración. El acuerdo fue reflejado en una Real Orden el 14 de abril de $1884^{14}$, época en la que Sagasta era Presidente del Gobierno y

12. Boletín Extraordinario de la Provincia de Logroño, 19 de octubre de 1868, n 127, 2. Bajo la cabecera del título del Boletín puede leerse: ¡Viva la libertad!, ¡Abajo los Borbones!, ¡Viva el sufragio universal!, ¡Vivan las Cortes Constituyentes!. En la segunda página aparece la siguiente disposición: "Habiéndose establecido los Seminarios de Calahorra y La Calzada hace pocos años, faltando a la más estricta justicia, y lastimando por consecuencia los legítimos intereses de esta Capital, la Junta revolucionaria en sesión celebrada el día 10 del presente mes, decretó lo siguiente: $1^{\circ}$ Quedan suprimidos desde este día los Seminarios de Calahorra y Santo Domingo de la Calzada. $2^{\circ}$ Los alumnos podrán trasladar su matrícula al Seminario de Logroño. $3^{\circ} \mathrm{Al}$ que no haga constar que ha cursado en esta ciudad durante el presente año no le serán aprobados los exámenes que deben sufrir al finalizar el mismo. Logroño 18 de octubre de 1868. El Presidente Ezequiel Lorza. P.A.D.L.J.R., El vocal Secretario, Anselmo Torralba.

13. Archivo Municipal de Calahorra (AMC), Sig. 3042/3 Cod. 4.2.2.2-13.

14. La Rioja, 29 de junio de 1892, p. 1. El periódico transcribió el texto íntegro de la Real Orden de 1884, que obra en el Archivo Municipal de Logroño, para demostrar a Calahorra como 
durante ese período se carteó con frecuencia con el alcalde de Logroño, Rodríguez Paterna respecto de este asunto.

En este clima fue nombrado para ocupar el gobierno de la diócesis calagurritana una figura que sería crucial en el conflicto latente entre Calahorra y Logroño y que se convertiría con el tiempo en el valedor de los intereses de la ciudad riojabajeña. El 27 de marzo de 1884, previa designación regia, fue nombrado por el Papa obispo de Calahorra, Antonio María Cascajares y se convertiría en una de las personalidades eclesiásticas más importantes de su época. Es conocido como destinó sus influencias políticas y eclesiásticas en el último decenio del siglo XIX a la consecución de un partido genuinamente católico que sustituyera al partido Conservador aunque como señalan Andrés-Gallego y Pazos, "no sólo no consiguió nada en el plano organizativo, sino que tuvo la mala virtud de suscitar el recuerdo de las camarillas semieclesiásticas atribuidas al Gobierno de Fernando VII e Isabel II y contribuyó a provocar la oleada anticlerical que se extendería hasta 1912"15.

Es innegable que la llegada de Cascajares a Calahorra fue recibida con alborozo por los calagurritanos y a su llegada a la diócesis en junio de 1884 fue acogido con innumerables muestras de afecto ya que como él mismo explicaban en una carta al Nuncio: "Sabían que era contrario a la traslación y fui no sólo querido sino adorado"16.

Efectivamente Cascajares no sólo fue recibido con enormes muestras de cariño sino que tuvo gestos de cercanía muy gratos a la población siendo especialmente relevante su intervención en 1885, momento en que Calahorra sufre una devastadora epidemia de cólera que se prolongó entre agosto y noviembre de dicho año. Con motivo de su despedida el periódico local El Calahorrano destacaba su actuación en esa crisis sanitaria y social, "cuando el cólera se cebaba en nuestra Ciudad veíamosle recorrer las casas de los atacados dejando a éstos recursos pecuniarios dando a todos consuelo y esperanzas; todos estos sacrificios fueron recompensados con la Cruz de Beneficiencia con que fue condecorado"17.

El posicionamiento de Cascajares respecto de la Traslación de la Silla Episcopal no fue bien recibido por el Ayuntamiento de Logroño, cuyo Alcalde, presionado por los propios vecinos y resto de concejales se veía en la obliga-

\footnotetext{
ya no estaba en vigor la Real Orden de 1877 que ésta esgrimiría en su favor con motivo del "motín de 1892"

15. Andrés-Gallego, J. y Pazos, A. M., La Iglesia en la España contemporánea, Ediciones Encuentro, Madrid, 1999, Tomo 1, p. 240.

16. Sáinz Ripa, E., Sedes Episcopales de La Rioja. Siglos XVIII y XIX. Obispado de Calahorra y La Calzada-Logroño, Logroño, 1997, pp. 447-448.

17. El Calahorrano, $\mathrm{n}^{\circ} 50$ de 13 de diciembre de 1891, p. 4.
} 
ción de volver a solicitar la mediación de Sagasta, al que se dirigiría el 13 de agosto de 1886 para "molestarle" en su función de Presidente del Gobierno ya que "esta Ciudad tiene puesta su atención en el asunto de la Silla Episcopal, y apenas pasa día sin que de ello se hable por todos y en todas partes"18. Está claro que en Logroño crecía la incertidumbre por una resolución favorable a sus intereses y tenían puestas todas sus esperanzas en la influencia de Sagasta. No hay duda tampoco del compromiso adquirido por Sagasta a favor de los intereses de la capital. No obstante, en la Nunciatura Apostólica, probablemente por la influencia del propio obispo de Cascajares, aunque se mostraba buena disposición a dar cumplimiento al art. 5 del Concordato, sin embargo, no consideraba que se cumplían las condiciones que el propio texto legal señalaba y así se lo hizo saber el Nuncio al alcalde de Logroño el 15 de noviembre de $1890^{19}$. Roma optó, de igual modo que lo había hecho en 1877, por dejar pasar el tiempo esperando que la dilación distendiera los ánimos y resolviera por sí mismo el problema. Todo apunta a que el propio Cascajares pese a su dinamismo y a ser muy apreciado en la diócesis calagurritana veía lastrada su tarea de gobierno por estas tensiones y él mismo pidió su traslado a otra diócesis. Finalmente por Decreto de la Reina Regente fue nombrado para la Iglesia y Arzobispado de Valladolid el 8 de diciembre de $1891^{20}$ y la noticia fue confirmada por El Calahorrano el 13 de diciembre de 189121, a la vez que comunicaba el nombramiento de Gobernador Eclesiástico en la figura de Santiago Palacios y CabeIlo, una figura central en el conflicto que vivirá Calahorra en 1892.

Podemos decir que a partir de la marcha del obispo Cascajares la prensa jugará un papel decisivo en la evolución de los acontecimientos posteriores. Como veremos inicialmente las rivalidades se dirimirán fundamentalmente entre el periódico provincial La Rioja y los periódicos calagurritanos La Rioja Católica y El Calahorrano. Todos ellos dejan de ser simples difusores de unos hechos para tomar partido a favor o en contra de la traslación de la silla Episcopal o lo que se interpretaba a nivel del pueblo entre los que defendían a Calahorra o a Logroño.

Para Calahorra el año 1891 concluía con la despedida de su obispo y con otra noticia difundida por El Calahorrano que, con ánimo de tranquilizar a los calagurritanos, afirmaba que la sede episcopal permanecería en Calahorra "después de haberse trabajado no poco en uno y otro sentido" ${ }^{\prime 22}$.

\footnotetext{
18. AML, sig. 122/1.

19. AML, sig. $122 / 1$.

20. Gaceta de Madrid, no 342 de 8 de diciembre de 1891.

21. El Calahorrano, $\mathrm{n}^{\circ} 50$ de 13 de diciembre de 1891, p. 4

22. El Calahorrano, $\mathrm{n}^{\circ} 51$ de 20 de diciembre de 1891, p. 3
} 
Antes de la marcha de Cascajares ya el periódico La Rioja había calentado motores difundiendo con todo detalle la llegada de Sagasta a Logroño donde fue recibido de forma multitudinaria. En una reunión el Alcalde, Marqués de San Nicolás, había dejado claro al ilustre visitante las principales demandas y también "que las mejoras más importantes y las que con más ardor deseaba Logroño eran: la realización del ferrocarril de Logroño a Pamplona y el traslado de la Silla Episcopal"23. A partir de la visita de Sagasta en la capital de la provincia se había creado una Comisión Especial del Ayuntamiento de Logroño que se había trasladado a la capital del reino con la finalidad de llevar a cabo cuantas gestiones fueran necesarias ante las personalidades previamente indicadas por Sagasta, entre ellas el ministro de Gracia y Justicia, Cos-Gayón y el propio Cánovas, a la sazón presidente del Consejo de Ministros. Pese a que el alcalde marqués de San Nicolás había dado cuenta al pleno del resultado de las entrevistas el 2 de enero de 1892, se mostraba prudente ya que un exceso de regocijo podía culminar con un desastre de la operación. La Rioja se hizo eco de forma pormenorizada del contenido del informe dejando claro además que Sagasta velaría porque la reivindicación llegara a buen puerto y mostrando una cierta seguridad por el desenlace favorable a Logroño ${ }^{24}$.

La lectura del periódico no debió sentar nada bien en Calahorra donde de nuevo se avivaba la polémica. El 5 de enero La Rioja se veía en la obligación de replicar a las opiniones que El Calahorrano había expresado al respecto, con el apoyo de otra publicación de Haro, conocida como El Postillón de la Rioja, según se desprende del propio artículo, que puede considerarse un Editorial del diario, que se daba por ofendido al acusársele, al parecer, de defender sólo a Logroño en detrimento de Calahorra y otros pueblos de La Rioja. La Rioja hacía expresión voluntarista de su defensa de toda la provincia:

Nosotros desearíamos que en nuestra provincia cesaran esos celos infantiles tan desarrollados en pueblos importantes de casi todas las de España; quisiéramos ver unidos a todos los que deben ser hermanos, trabajando por el engrandecimiento de la provincia entera y si la ley manda que un Obispado venga a Logroño y al Ilegar el día de cumplirla se ve perjudicada alguna ciudad, en vez de reproches sobre injustos, contraproducentes; $\ldots{ }^{25}$.

El nerviosismo crecía en ambas partes prueba de ello es la reiterada petición realizada el 26 de febrero de 1892 por el Alcalde, Marqués de San Nicolás tanto a Sagasta, su gran valedor, como al Presidente del Consejo, Antonio Cánovas del

23. La Rioja, $\mathrm{n}^{\circ} 806$ de 28 de septiembre de 1891, p. 1.

24. La Rioja, $\mathrm{n}^{\circ} 886$ de 3 de enero de 1892 p. 1

25. La Rioja, $\mathrm{n}^{\circ} 887$ de5 de enero de 1892, p. 1. 
Castillo ${ }^{26}$. Todo indica que en abril el expediente comenzó a moverse en el ministerio de Justicia, aunque una nueva complicación surge en el camino. Al parecer el supuesto apoyo otorgado por el obispo Gabino Catalina del Amo había desaparecido del expediente iniciado ${ }^{27}$ y sin el informe favorable del obispo era imposible continuar en su resolución. Además estaba claro que en ese momento ya no había obispo en la diócesis de Calahorra sino un Vicario Capitular, Santiago Palacios y Cabello que había sido elegido por el Cabildo el 29 de enero de 1892.

Así mientras en Logroño seguían presionando a Sagasta, el Ayuntamiento de Calahorra recibió una comunicación del Vicario Capitular el 21 de marzo de 1892, participándole que el obispo Auxiliar de Toledo, Valeriano Menéndez iba a ser nombrado de forma inminente Obispo de la diócesis de Calahorra y La Calzada. Santiago Palacios y Cabello advierte al Alcalde de que el nombramiento no es oficial todavía, pero el alcalde Cruz Félez con fecha 22 de marzo envía una rápida carta de felicitación al posible designado que, a vuelta de telégrafo, le agradece su posición pero le deja claro que el "nombramiento no está hecho sino acordado ${ }^{28}$. De este modo Valeriano Menéndez, obispo de Tamasso y Auxiliar de Toledo deja claro que existe un acuerdo entre el poder civil y el eclesiástico pero que la designación, como tal, no se había efectuado. Los rumores llevan a Sagasta a escribir al alcalde de Logroño pidiendo calma, "estad tranquilos" recomendó ${ }^{29}$.

A partir de estos momentos la temperatura pública de la polémica va subiendo de tono y trascendiendo el ámbito de la propia prensa local, es más, La Rioja el día 3 de abril de 1892, busca un acicate en sus informaciones haciéndose eco de lo publicado en otros medios como El Liberal, en el que se trascribía del anterior lo siguiente:

El arzobispo de Valladolid ha dejado vacante la silla de Calahorra y la Calzada. Esta Silla según el Concordato, ha de ser trasladada a Logroño, y el nuevo obispo, que lo será el auxiliar de Toledo, irá desde luego a la capital de La Rioja. Ni Roma ni el Gobierno han querido disgustar al señor Sagasta ${ }^{30}$.

La Rioja se ve en la obligación de apostillar contra su rival: "Como se ve difieren bastante estas noticias de las publicadas por El Calahorrano". Se refería

26. AML, sig. 122/1. Carta del Alcalde de Logroño dirigida a Sagasta fechada el 26 de febrero de 1892.

27. AML, sig. 122/1.

28. AMC, Sig. 3.042/15 Cod. 4.2.2.9. Los telegramas están depositados en el Archivo Municipal de Calahorra y en el texto del Alcalde de Calahorra existe un error al confundir el apellido Menéndez del posible Obispo con el de Méndez.

29. AML, sig. 122/1.

30. La Rioja, $\mathrm{n}^{\circ} 960$ de 3 de abril de 1892, p. 2. 
en concreto a las afirmaciones realizadas unos días antes por el periódico de Calahorra en las que según el periódico logroñés se había afirmado:

"Aunque estamos convencidos de que el nombramiento del Ilmo. señor Obispo Auxiliar de Toledo... es ya un hecho, nos abstenemos de todo género de agradables espansiones (sic) hasta que oficialmente tengamos noticia de tan plausible acontecimiento para esta antiquísima Ciudad episcopal"31.

Es a partir de este momento cuando los acontecimientos se precipitan ya que el esperado nombramiento no se efectuaba ni en un sentido ni en otro. El 13 de abril de abril de 1892 la Corporación Municipal de Calahorra se reunió en sesión extraordinaria ya que "las noticias recibidas en el día de ayer sobre traslación de la silla episcopal a Logroño son del todo desfavorables para esta Ciudad"32.

La decisión adoptada por los munícipes calagurritanos consistió en pedir con carácter de urgencia ayuda al anterior obispo de la diócesis Antonio María Cascajares para que haciendo uso de sus influencia suplicara a la Reina Regente que no se llevara a efecto la traslación ${ }^{33}$. Una comisión presidida por el liberal Vidal Roques trasladaría a Madrid para acompañar al obispo de Valladolid que ya había anticipado sus impresiones:

Es cierto que Sagasta ha escrito al Alcalde de Logroño que había desbaratado el nombramiento de obispo, y que la traslación se haría. Si esto es cierto, veo muy mal el asunto y lo considero casi perdido para Calahorra. Pues entiendo que se ha hecho todo a espaldas del Nuncio y del Ministro, entre Sagasta, Cánovas y Roma, y con el mayor sigilo ${ }^{34}$.

Sin embargo Cascajares aconseja una acción inmediata por parte de los calagurritanos si no querían darlo todo por perdido y que se iniciaría "sin perder un momento por hacer una instancia clara y enérgica, al Presidente del Consejo, firmada por el vecindario entero". El texto debía ser llevado por el propio alcalde, un diputado provincial y el diputado Tirso Rodrigañez, sobrino de Sagasta, todo ello sin olvidar que el propio cabildo debía hacer lo mismo dirigiéndose al Nuncio. Según Cascajares, si así se ejecutaba el plan "tengo por cierto que se parará el golpe"35.

La Comisión Municipal se trasladó a Madrid para entrevistarse Cánovas, entonces Presidente del Gobierno, así como, al Ministro de Gracia y Justicia y

31. La Rioja, no 995 de 29 de marzo de 1892, p. 2.

32. AMC, Actas Municipales, 13-IV-1892, sig. 141/3 Cod. 1.3.0.7.

33. AMC, Actas Municipales, 13-IV-1892, sig. 141/3 Cod. 1.3.0.7.

34. Carta de 16 de abril de 1892 de Cascajares al alcalde de Calahorra, AMC, Sig. 3.042/15 Cod. 4.2.2.9. El subrayado está en el texto original.

35. AMC, Sig. 3.042/3-15 Cod. 4.2.2.9. El subrayado está en el texto original. 
al Nuncio ${ }^{36}$. Como Rodrigáñez se encontraba en Córdoba, los calagurritanos recurrieron al senador riojano por el distrito de Santo Domingo, Juan Francisco Cardenal y Rabenet al que trasladaron el encargo de gestionar la audiencia con la Reina.

Se reunieron con el Ministro de Gracia y Justicia y después con el subsecretario del Ministerio y el 29 de abril de 1892, con la Reina, acto al que debían presentarse "de rigurosa etiqueta" ${ }^{37}$ y al que acudieron acompañados por el arzobispo Cascajares, el diputado Rodrigáñez y el senador Cardenal. De la entrevista, informaron al alcalde resaltando que se les había tranquilizado con un "no tengan Vs. Cuidado"38. La prudencia se convierte en la norma de comportamiento para evitar que las alegrías demasiado tempranas pudieran dar al traste con las gestiones realizadas:

Tampoco creyeron conveniente los ediles calagurritanos reflejar en el acta del pleno celebrado el 15 de mayo todos los pormenores de las gestiones realizadas por la Comisión en Madrid, fueron enormemente discretos, aunque dejaron claro el interés que Sagasta tenía en el asunto y cómo estaba utilizando toda su influencia para mediar a favor de la causa de Logroño.

\section{El motín de junio de 1892: la explosión social}

Llegados a este punto podemos decir que la cuestión de la traslación de la Silla episcopal de Calahorra a Logroño había producido un enfrentamiento entre ambas ciudades y provocaba sentimientos encontrados entre sus habitantes. Resulta muy interesante profundizar en el conocimiento de las causas porque lo que aparentaba ser una divergencia más religiosa que política había terminado por convertirse en un problema que enfrenta a municipios, a periódicos, a unos y a otros con el gobierno y con menos virulencia con la Santa Sede. Para Logroño conseguir el privilegio de convertirse en cabecera de una de las diócesis más antiguas de España era una cuestión de prestigio que podía dar empaque a su vocación capitalina, era una ciudad en claro crecimiento demográfico y con una expansión económica más importante. Por el contrario, Calahorra en aquellos años finiseculares vivía una situación de estancamiento más evidente y con problemas sociales muy arraigados, que encontraba la solidaridad de otros municipios como Haro y Santo Domingo.

Tampoco pueden obviarse en el análisis la problemática social de España ni tampoco que de los últimos años del siglo XIX, fue precisamente 1892, el más conflictivo por el incremento del precio del trigo como consecuencia de la

36. AMC, Sig. 3.042/3-15 Cod. 4.2.2.9.

37. AMC, Sig. 3.042/3-15 Cod. 4.2.2.9.

38. AMC, Sig. 3.042/3-15 Cod. 4.2.2.9. 
subida de aranceles y el incremento de la presión fiscal decretada por el gobierno conservador. El impuesto de consumos que gravaba artículos básicos de la dieta como el pan, enfrentaría a ciudadanos y concejos. Como señala Gil Andrés "el odiado impuesto de consumos será el blanco de las iras populares, concentrándose los motines en el verano, cuando normalmente se renuevan los arriendos al comenzar el año económico"39. Por tanto podemos decir que "en La Rioja, el siglo se despedía lleno de hambres y de desastres políticos nacionales ${ }^{40}$. Esta consideración, aunque breve, es suficiente para situarnos en un contexto social y económico muy desfavorable para la población, un terreno abonado para el incremento de las revueltas que expresarían un descontento en el que influían ya de manera notable el ascenso de las ideologías socialistas y anarquistas que recorrían la península de punta a cabo. A mi entender, este descontento social, será elemento inseparable de la crisis política provocada por el intento de trasladar la silla episcopal.

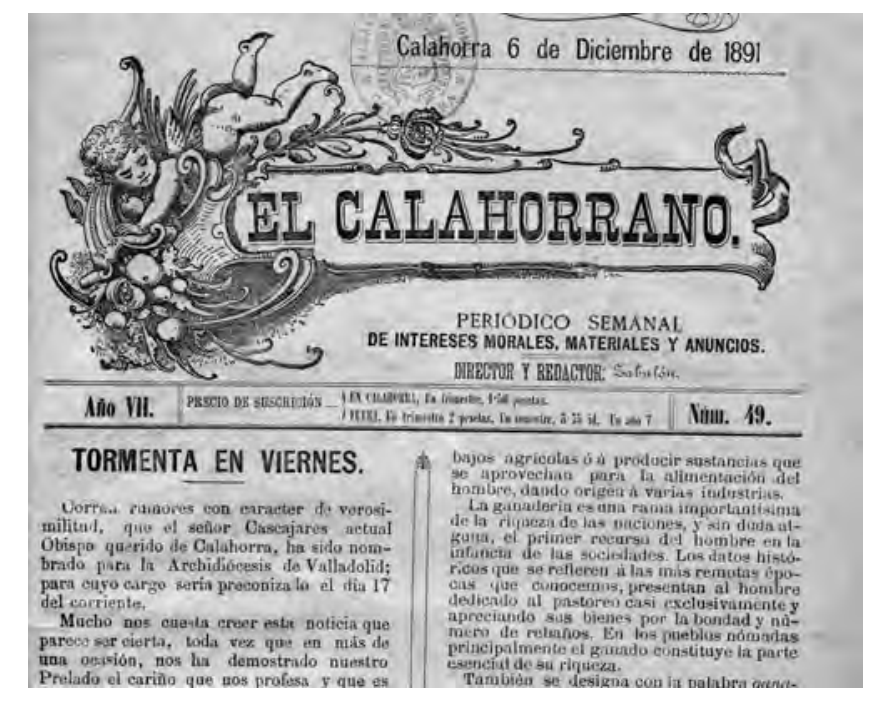

Lám. 2. El Calahorrano no 49 de 6 de diciembre de 1891.

39. Gil Andrés, C., Echarse a la calle. Amotinados, huelguistas y revolucionarios (La Rioja, 1890-1936), Prensas Universitarias de Zaragoza e Instituto de Estudios Riojanos, 2000, pp. 34-35. Para analizar la situación social puede verse del mismo autor, Protesta popular y orden social en La Rioja de fin de siglo, 1890-1905, Instituto de Estudios Riojanos, Logroño, 1995.

40. Sáinz Ripa, E., Sedes Episcopales..., p. 471. 
La prensa local ya había caldeado suficientemente el ambiente y la Corporación municipal de Calahorra se había reunido el 7 de junio de 1892, en una sesión extraordinaria, para aprobar el escrito que por una Comisión sería elevado al Ministro de Gracia y Justicia ${ }^{41}$. El pleno había sido convocado a las nueve de la noche, una hora en la que por esas fechas los agricultores, la mayoría de la población activa de la ciudad, regresan a sus casas después del trabajo. Alrededor del Ayuntamiento, en la plaza del Raso, se produjo una enorme concentración de personas lo que obligó al alcalde a telegrafiar al gobernador que "la población en masa (está) por las calles, ánimos muy exaltados" y en otro despacho de la misma fecha se le advierte que "una comisión se ha acercado a mi autoridad diciendo no quieren pertenecer a la provincia de Logroño" y, por último, comunica que "han sido apedreadas la casas de los canónigos"42.

La Rioja cuenta el 9 de junio detalles de lo sucedido en Calahorra y apunta como origen de los desórdenes rumores que supuestamente habían llegado de "Roma y por conducto de los religiosos de aquella ciudad se habían recibido noticias referentes al traslado de la Silla" ${ }^{\prime \prime 3}$. La concentración se inició a partir de las diez de la noche y se fueron creando grupos que discutían acaloradamente el asunto de la traslación. Al incrementarse el número, según La Rioja, tomaron "una resolución bastante violenta: se dirigieron a casa de los canónigos señores Ruiz de la Cámara, López y Fernández y beneficiados Sres. Ruiz de Velasco y Zuada". Una vez allí se produjeron gritos "nada piadosos" y se arrojaron piedras a las casas de los canónigos citados. El motín duró hasta la una de la madrugada. Según la prensa lo sorprendente radicaba en que si durante tres horas el gentío se apoderó de las calles, "los serenos deben presenciarlo, la guardia civil da parte del hecho, lo que parece probar que lo ha visto, y sin embargo nadie dice las medidas que se tomaron para disolver a los grupos, o para detener a quien hubiese cometido actos penados por el Código". La narración de los hechos se amplía con la información de que la estación había sido tomada y que el tren de Zaragoza tuvo que parar en Lodosa para atender al Sr. Franco, inspector de vigilancia, que fue el primero en desplazarse de Logroño a Calahorra con cuatro parejas de la benemérita y que, al llegar a Calahorra, fue "agredido por las turbas sufriendo varias contusiones graves en la cabeza y hombros, producidas por piedra y palo". Parece ser, según cuenta el periódico, que "como había salido precipitadamente de Logroño iba desarmado y quizás a esta causa debió su salvación". Finalmente el tren que procedía de Zaragoza llegó a Logroño a las once. La estación permanecía invadida a la espera de la llegada del Gobernador, se presumía que varios guardias civiles pudieran estar

41. AMC, Actas Municipales, 7 de junio de 1892, sig. 141/3 Cod. 1.3.0.7.

42. Las copias de los telegramas que narran lo sucedido se encuentran en AMC, Sig. 3.042/3-15 Cod. 4.2.2.9.

43. La Rioja, $n^{\circ} 1.015$ de 9 de junio de 1892, pp. 1-2. 
heridos y se sabía que el canónigo Sr. Ruiz de la Cámara había sido atropellado también "por las turbas". La Rioja explicaba que la revuelta continuaba puesto que seguían apedreándose viviendas particulares y se habían pedido refuerzos. De igual forma se anuncia que en el tren de las cinco de la madrugada habían partido para Calahorra los Sres. Gobernadores Civil y Militar con el segundo batallón del regimiento de Burgos ${ }^{44}$.

El Alcalde de Calahorra, visiblemente afectado y desbordado por los acontecimientos, el día 8 de junio, envía varios telegramas al Gobernador, expresándole que "a consecuencia de los acontecimientos me hallo gravemente enfermo, he delegado mi autoridad en la militar". El siguiente telegrama expresa que "la autoridad militar no admite jurisdicción y delegó en el $2^{\circ}$ Teniente de Alcalde". Según el telegrama parece ser que todo ello fue consecuencia de estar "lesionado por una pedrada que he recibido en la tarde de hoy en defensa del inspector ${ }^{\prime \prime 4}$. Como se deriva del texto de los telegramas la gente del pueblo se había lanzando a la calle y ni el Alcalde ni la Guardia Civil conseguían restablecer el orden por lo que hubo que pedir refuerzos mientras la noticia trascendía fuera del ámbito provincial. Gil Andrés refiere "que las autoridades y las fuerzas del orden son insultadas y apedreadas y el gobernador civil, que sufre en su misma piel la hostilidad de los revoltosos, se ve obligado a resignar el mando en la autoridad militar" ${ }^{\prime \prime 4}$. La Vanguardia es el diario de difusión nacional que se detiene en este detalle, al informar que "el alcalde señor Félez se encuentra enfermo a consecuencia del disgusto que le ha producido el motín" ${ }^{\prime 47}$ razón por la que delegó su autoridad en el primer teniente de Alcalde y además, apostilla, los diputados provinciales señores Redal y Tejada presentaron su dimisión.

Existen diversas crónicas sobre lo sucedido aquellos días 7, 8 y 9 de junio de 1892 pero todas coinciden en lo principal. Así nos describe los sucesos José $\mathrm{M}^{\mathrm{a}}$ Solano, quien señala que "con motivo de la traslación de la silla episcopal de Calahorra, se ha alterado el orden público en esta población. Los amotinados apedrearon las casas de los Canónigos y de los partidarios de la traslación de la Silla. A Calahorra llegó un ejército de Infantería, otro de Ingenieros por ferrocarril y otro ejército de Caballería. El día 9, a las 12 y 23, han llegado a Calahorra las tropas anunciadas. Grupos de mujeres y niños recibieron a los soldados con silbidos; los hombres están dedicados a sus ocupaciones habituales. Siguen los ánimos muy excitados y los revoltosos en su mayoría mujeres y arrapiezos, insultaron y apedrearon al Gobernador cuando salía del

44. La Rioja, $\mathrm{n}^{\circ} 1015$ de 9 de junio de 1892, pp. 1-2.

45. AMC, Sig. 3.042/3-15 Cod. 4.2.2.9

46. Gil Andrés, C., Echarse a la calle..., p. 331.

47. La Vanguardia, $n^{\circ} 3.262,10$ de junio de 1892, p. 5. 
Ayuntamiento donde presidió su sesión. El ejército de infantería tuvo que hacer varios disparos al aire, para contener y dispersar a los amotinados. Los canónigos tuvieron que salir disfrazados de Calahorra" ${ }^{48}$.

En relación a la huída de los canónigos, es bien ilustrativa la noticia publicada en La Rioja, el 11 de junio, donde se describe la forma en que habían llegado a Rincón de Soto disfrazados los canónigos partidarios de la traslación ${ }^{49}$. Aunque no fue este el único lugar al que huyeron. La versión del periódico de la capital sobre la forma en que tuvieron que huir los canónigos queda ratificada por la que difunde la publicación calagurritana La Rioja Católica en la que se cuenta la aventura de la huída del arcediano el día 8 de junio: "...que al bajar a la estación parte del pueblo persiguiendo al delegado del Gobernador, apareció el M.I. Arcediano D. Juan Francisco Ruiz de la Cámara; y los amotinados, que suponían al señor Ruiz de la Cámara partidario de la traslación de la Silla Episcopal, le acometieron dándole varios golpes y quitándole el manteo y el sombrero. El Sr. Ruiz de la Cámara se refugió en la oficina de telégrafos, donde fue defendido por la Guardia civil. Los amotinados apedrearon la casa, rompiendo los cristales y dejando de una pedrada casi inútil el aparato. En la madrugada, escoltado por la Guardia Civil, el Sr. Arcediano Ilegó a Pradejón, disfrazado" ${ }^{\prime 50}$.

El tumulto se prolongó hasta la una de la madrugada y las autoridades civiles quedaron desbordadas ante la fuerza de la revuelta. Como en Fuenteovejuna, nadie había visto nada. El Gobernador Civil pese al traslado de las tropas del batallón de Albuera, la resistencia ciudadana seguía en las calles y él mismo fue cercado por hombres y, sobre todo, por mujeres como Saturnina Mangado, apodada la "San Juan del Huerto" que en un acto, considerado heroico por la ciudadanía, arrancó "medio bigote" al Gobernador ${ }^{51}$. La Vanguardia también se

48. Solano Antoñanzas, J. M., El Gobierno Eclesiástico de la vasta Diócesis de Calahorra. Imprenta Gutenberg, Calahorra, 1967, p. 123.

49. Así cuenta La Rioja, no 1.017 de 11 de junio de 1892, p. 2, el asunto de los "Sacerdotes huidos. Ayer mañana aparecieron en Rincón de Soto, disfrazados y envueltos en mantas, el conocido y elocuente canónigo, don Cruz Ochoa, y los señores Ruiz de Velasco y Zunda que habían logrado dejar el pueblo sin que nadie se apercibiera y llegaron a Rincón de Soto donde tomaron el tren. Con la salida de estos señores no quedaba ninguno en Calahorra que pudiera tener agresiones de las masas".

50. La Rioja Católica, n 24 de 16 de junio de 1892, pp. 1 y 2.

51. Gutiérrez Achútegui, P., Historia de la muy noble, antigua y leal ciudad de Calahorra, Amigos de la Historia de Calahorra, Logroño, 1981, p. 287. Pedro Gutiérrez tenía en aquellos momentos 12 años $y$, por tanto, son parte de sus recuerdos los que transmite en el libro citado. Para ampliar el conocimiento sobre la figura de Saturnina Mangado, "La San Juan del Huerto" es de interés el artículo publicado por Cinca Martínez, J. L., "Unas notas sobre Saturnina Mangado (La San Juan del Huerto) y su relación con los sucesos de 1892 en Calahorra", en Kalakoricos, $\mathrm{n}^{\circ}$ 9, 2004, pp. 317-324. 
hizo eco del motín y en concreto de este episodio, al contar que "a la llegada de las tropas a Calahorra han sido vitoreadas. Dícese que una mujer del pueblo ha dado una bofetada al gobernador civil. Las niñeras se distinguen por sus insultos a las autoridades ${ }^{52}$.

El protagonismo de las mujeres no sólo estuvo en la calle sino también en la sesión municipal que se celebró a fin de calmar los ánimos. En el salón de sesiones una de sus representantes María Encarnación Antoñanzas, tomó la palabra y realizó las peticiones ante el Gobernador, Sr. Camacho al que solicitaron que telegrafiara a la Reina para transmitir sus reivindicaciones respecto de la silla episcopal. Concluida su tarea, según La Rioja Católica, abandonando luego ordenadamente y con merecidos aplausos del pueblo el salón ${ }^{53}$. La llegada de las tropas para escoltar la marcha del gobernador de la sesión municipal también contó con la peculiar bienvenida que les ofrecieron, mediante abucheos, las mujeres calagurritanas ${ }^{54}$.

Ante lo complicado de la situación el Gobernador militar de la provincia, el General de brigada Fermín Jaúdenes y Álvarez asumió el mando que le resignó el Gobernador civil, absolutamente impotente para hacer frente a la situación. Declarado el estado de sitio el mismo día 9 de junio se prohibió la aglomeración de personas, no pudiendo formarse grupos de más de tres y se apelaba a la sensatez del honrado vecindario para evitar dar cumplimiento al rigor de la norma decretada ${ }^{55}$. Todo apunta a que la intervención del Vicario capitular, Santiago Palacios y Cabello, fue decisiva en la resolución de la crisis. Según la versión de La Rioja Católica respecto a su aparición en el escenario de los acontecimientos para pacificar la situación fue recibida por "una ovación indescriptible". Fue él quien "en compañía de otros señores sacerdotes, una comisión del Ayuntamiento y otras personas respetables, entró en el cuartel, habiéndole franqueado la entrada, en medio de vivas atronadores, aquel ejército de mujeres" ${ }^{\prime \prime 6}$.

Fue el Vicario capitular, que en definitiva, era la máxima autoridad eclesiástica al carecer de obispo propio y un representante notable de la defensa de la permanencia de la Sede episcopal en la ciudad, el que tuvo un papel crucial en la tarea de calmar los ánimos. Santiago Palacios se desplazó al cuartel de la ciudad $^{57}$ donde se encontraba un batallón del Regimiento de Burgos, allí habló

52. La Vanguardia, $\mathrm{n}^{\circ} 3.262,10$ de junio de 1892, p. 5.

53. La Rioja Católica, no 23 de 9 de junio de 1892, p.3.

54. La Rioja Católica, no 24 de 16 de junio de 1892, p. 4.

55. AMC, Sig. 3.042/3-15 Cod. 4.2.2.9.

56. La Rioja Católica, n 24 de 16 de junio de 1892, p. 2.

57. El cuartel estaba situado en el lugar en que actualmente se encuentra el Colegio de las Madres Teresianas, muy próximo a la Catedral y al Palacio Episcopal. 
con los Gobernadores civil y militar, a los que la ciudadanía no dejaban salir del cuartel aunque proferían gritos a favor del ejército y le pidió al primero apoyo en la defensa de las reivindicaciones de Calahorra, una ciudad que había "sido herida en lo más vivo", insistió en el deseo de los calagurritanos de conservar sus tradiciones y, según La Rioja Católica, pidió que se pusiera "en conocimiento del Gobierno lo que sucede hoy en Calahorra, lo que quiere la ciudad..." ${ }^{58}$.

El Gobernador Civil, según narra La Rioja Católica, después de las palabras pronunciadas por el Vicario Capitular, que se expresó como si estuviera en el púlpito, prometió su apoyo a las reivindicaciones de los calagurritanos. El Sr. Camacho insistió en que se le había tomado por enemigo cuando en realidad no lo era, insistiendo en que siempre se había interesado por las cosas de Calahorra, pero añadió que desde el cuartel en que se encontraban poco podían hacer a favor de la causa que tanto preocupaba y propuso trasladarse a la Casa Consistorial.

Para facilitar la salida del cuartel por parte de las autoridades, el Vicario Capitular, una vez negociadas las peticiones que debían elevarse al gobierno, dictó un Bando, facultad propia de una autoridad civil y pidió a los congregados "debe retirarse el pueblo de las inmediaciones del cuartel, dejando el tránsito libre para que pueda salir el señor Gobernador a la casa de la ciudad". Además el vicario prometía informar al pueblo de lo que contestara Madrid "por medio de hojas impresas" 59 .

Esta dejación de funciones de la máxima autoridad civil de la provincia en el Deán del Cabildo sería objeto de severa crítica por parte del periódico La Rioja que reprochaba a Camacho su actuación "como si su autoridad hubiera desaparecido al resignarla el jueves en manos del Sr. Deán", e insiste en que el gobernador de la provincia está para gobernarla y "para hacer entender a los alcaldes, que sus facultades políticas, no son independientes, sino subordinadas por ley a la dirección del Gobernador Civil"60.

58. La Rioja Católica, no 24 de 16 de junio de 1892, p. 2.

59. AMC, Sig. 3.042/3-15 Cod. 4.2.2.9. Tanto el Bando del Gobernador Militar como el del Vicario Capitular fueron impresas en los talleres de la imprenta de Andrés C. Ciriano, director de El Calahorrano.

60. La Rioja, nº 1.019 de 14 de junio de 1892, p. ñ1. El periódico no sólo emitía una opinión crítica sobre la actitud del Gobernador sino también sobre la autoridad eclesiástica que había abusado de su preeminencia social: "Seguramente pensarán algunos que son estas quejas arrancadas por la contrariedad producida en nosotros por esa manifestación: nada de eso. Nosotros censuraremos que se utilice el púlpito para ciertas exhortaciones, que se emplee la influencia de los arciprestes, para recoger firmas y sellos que las leyes no consienten estampar; que la pluma cortada para redactar pastorales, se emplee en escribir bandos que dejan mal parado a nuestro juicio, el principio de autoridad... Lo que nos proponemos hoy censurar, con abstracción completa de otros aspectos, es que se prescinda en absoluto del señor Camacho, 
Resulta Ilamativo como los manifestantes que, en su primer impulso, habían dirigido sus iras contra los canónigos del Cabildo catedralicio fueran pacificados por la autoridad eclesiástica ante la impotencia de la autoridad civil. Todo lo ocurrido puso en evidencia la debilidad y legitimidad de las autoridades civiles en un sistema político que, ya entonces, muchos consideraban agotado. Fuera como fuere, lo cierto es que una vez trasladados al Ayuntamiento, las autoridades civiles y eclesiásticas acordaron enviar telegramas al Mayordomo Mayor de la Reina Regente, el conde de Sotomayor y al Nuncio Apostólico a quienes piden su apoyo ${ }^{61}$.

\section{Los ecos del motín calagurritano}

Hemos visto hasta ahora fundamentalmente el impacto del motín de junio de 1892 a través de la prensa local y provincial, en concreto El Calahorrano, La Rioja Católica, El Postillón de la Rioja y La Rioja, pero la repercusión de los sucesos de Calahorra trascendió primero a la prensa de las provincias limítrofes, a la nacional y simultáneamente a la prensa internacional aunque cada publicación hacía su particular valoración de los acontecimientos según su posicionamiento político.

Conocemos algunas de las repercusiones ajenas al ámbito provincial porque el propio diario La Rioja difundía las que consideraba convenientes bien para fundamentar su posición, bien para rebatirla. Así sabemos que El Movimiento Católico "culpa de lo sucedido a la imprevisión del ayuntamiento calahorrano"62. Por su parte, La Correspondencia Militar, "emplea tono humorístico y dice: Pimientos riojanos. Los de Calahorra se han alborotado, no los pimientos, sino los vecinos. ¿Motivo del belén? Que se trata de trasladar a otro punto la diócesis allí establecida. Y los calagurritanos no pueden consentir en quedarse sin obispo, canónigos y demás. Por lo cual y como primera providencia, tomaron ayer la de apedrear las casas de los canónigos y de los partidarios de la traslación del Obispado. Sin duda los querían elevar a cardenales. Y que un guardia civil resultó herido. Víctima del celo religioso de aquella población. El Nervión explica no comprender la necesidad del traslado; pero que los calagurritanos se quedarán ahora sin obispo, con tanto más motivo cuanto que no pueden permanecer allí dignamente los canónigos que han sido apedreados (hace extensivo el argumento al Obispo)" ${ }^{\prime 63}$.

para gobernar la provincia, como si su autoridad hubiera desaparecido al resignarla el jueves en manos del señor Deán, como dijo un diputado en las Cortes, o en las del señor Jaúdenes como sucedió, para lo que se refiere a Calahorra. Por eso decimos al principio «Basta ya, señor Camacho", el gobernador está para gobernar la provincia o no sabemos castellano, y para hacer entender a los alcaldes, que sus facultades políticas, no son independientes, si no subordinadas por la ley a la dirección del Gobernador Civil".

61. AMC, Sig. 3.042/3-15 Cod. 4.2.2.9.

62. La Rioja, $\mathrm{n}^{\circ} 1.018$ de 13 de junio de 1892, p. 1.

63. La Rioja, $\mathrm{n}^{\circ} 1.018$ de 13 de junio de 1892, p. 1. 
Por su parte, La Libertad de San Sebastián explicaba que "la ciudad de Calahorra se ha sublevado, oponiéndose a que la sede en ella establecida se traslade a Logroño. Quiere su obispado la patria de Quintiliano, y lo defiende a pedradas y a palos. Los calagurritanos han apedreado al gobernador y apaleado bárbaramente a algunos sacerdotes acusados de ser partidarios de la traslación de la diócesis. Este hecho evidencia que se trata de una cuestión económica. Maldito si Calahorra se preocupa con tener obispo, desde el punto de vista religioso. Ve en él un modo de vida, algo así como una feria. Lo mismo defendería la permanencia de una guarnición. Al canónigo que desea trasladarse a Logroño, lo apalean, y al que desea continuar calagurritano, lo llevan en andas. A esto queda reducida la religiosidad de los amotinados" ${ }^{\prime 64}$.

A su vez El Liberal Navarro se hace eco en primer lugar de lo que relataba El Postillón de La Rioja, un periódico de Haro como se ha expresado y que se posiciona próximo a las reivindicaciones calagurritanas ${ }^{65}$. Posteriormente el diario navarro publicará la versión de La Correspondencia, argumentando que el Concordato debía cumplirse por ser una ley pactada y detallaba la salida de los canónigos entre los que se encontraba el "conocido y elocuente canónigo don Cruz Ochoa, que vino a Pamplona el mismo día, y los señores Ruiz de Velasco y Zunda que habían logrado dejar el pueblo sin que nadie se apercibiera y llegaron a Rincón de Soto donde tomaron el tren para Zaragoza"66. En La Correspondencia de España, se prestará especial atención al conflicto y también a la intervención del diputado Rodrigáñez en el Congreso de los diputados interpelando al Gobierno sobre lo acontecido en Calahorra ${ }^{67}$.

Desde Navarra El Tradicionalista que, de algún modo suscribía la posición de los periódicos calagurritanos, consideraba que había comenzado el motín "aunque así no podía apellidarse en los primeros momentos, con la presentación en el Ayuntamiento de una Comisión del pueblo que pedía no pertenecer a la provincia de Logroño, por ser ésta una capital que, no contenta de ser la niña mimada de los gobiernos y principalmente del señor Sagasta, quiere arrebatar a Calahorra el principal elemento que le da vida. Y contaba como al llegar la milicia movilizada por el gobierno había sido recibida al grito de "No queremos tropa sino obispo" ${ }^{\prime 68}$. Al día siguiente describe El Tradicionalista, con todo detalle, la salida del gobernador civil, "montado en un caballo de tropa y protegido por cuarenta jinetes de Albuera con batidores delante y llevando a su lado un capitán y los oficiales del gobierno. Una nube de piedras cayó sobre

64. La Rioja, no 1.018 de 13 de junio de 1892, p. 1.

65. El Liberal Navarro, $\mathrm{n}^{\circ} 1.752$ de 11 de junio de 1892, p. 1.

66. El Liberal Navarro, $\mathrm{n}^{\circ} 1.753$ de 13 de junio de 1892, p. 1.

67. La Correspondencia de España,no 12.482 de 9 de junio de 1892, pp. 1 y 2; n 12.483 de 10 de junio de 1892, p. 2 y n 12.484 de 11 de junio de 1892, p. 1.

68. El Tradicionalista, Diario de Pamplona, $\mathrm{n}^{\circ} 1.643$ de 11 de junio de 1892, p. 2. 
los expedicionarios" que tuvieron que llegar por una ruta falsa a la estación de ferrocarril. "Al partir el tren tuvo necesidad la fuerza de hacer un disparo al aire, teniendo que oír toda clase de insultos proferidos en su mayoría por mujeres. Durante todo el día la Plaza del Raso, a la entrada del pueblo, ha estado ocupada por millares de mujeres y niños que lanzaban piedras sobre cuántos intentaban penetrar en la población" ${ }^{69}$. Otra crónica que, como vemos, hace hincapié en el papel de las mujeres en la revuelta popular.

El periódico La Vanguardia desde el principio, mantuvo a sus lectores perfectamente informados de lo ocurrido en Calahorra. Es significativo que junto a la narración del incidente con el Gobernador Civil, se anuncie la posibilidad de declaración de una huelga en Barcelona ya que según señala estaba "siendo este asunto el tema de todas las conversaciones hoy en esta capital. Aquí se dice que el capitán general de Aragón ha recibido órdenes superiores para que tenga preparadas fuerzas del ejército para salir al primer aviso en dirección a Barcelona", la adopción de medidas represivas en Madrid y cómo las "noticias recibidas hoy confirman que sigue la excitación de los ánimos en Calahorra"70. Es decir, había un malestar social que estaba explosionando en toda España.

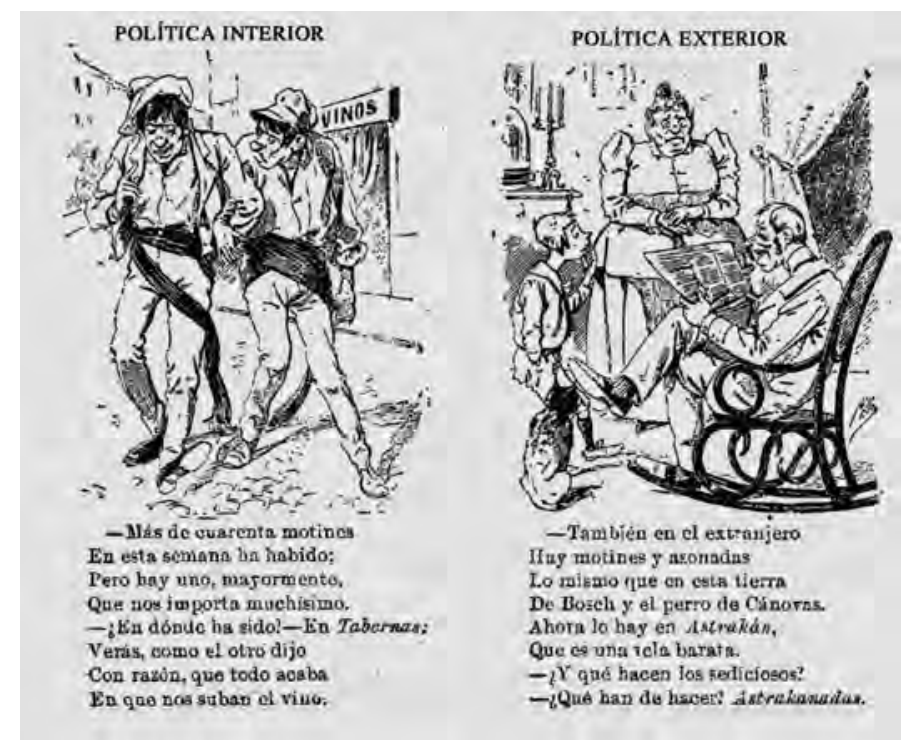

Lám. 3. Chistes alusivos a los motines en España, Blanco y Negro, 17 de julio de 1892, p. 14.

69. El Tradicionalista, Diario de Pamplona, $\mathrm{n}^{\circ} 1.644$ de 12 de junio de 1892, p. 2.

70. La Vanguardia, no 3.263, sábado, 11 junio 1892, p. 5. 
Por su parte el periódico madrileño La Libertad $^{11}$, se pone en contra de los calagurritanos porque cree que debe cumplirse el Concordato y que se han cumplido todas las condiciones salvo una nueva visita del Nuncio, considerando por tanto que "las pretensiones del vecindario sedicioso de Calahorra son injustas en el fondo e incalificables en la forma, y que el Gobierno ha hecho perfectamente en reprimir con mano firme tantos desmanes" ${ }^{\prime 72}$. Es interesante ver el seguimiento que cada medio escrito hace de sus oponentes y, en este caso, La Libertad publica la versión de El País, en el que se culpa a los Gobernadores de Logroño y Barcelona de la actuación en ambas localidades y critica que sigan en sus puestos. El País dice de Calahorra que "conviene a pesar de todo no echar en el olvido que ese motín religioso ha estallado bajo el Gobierno que se dice la más firme garantía de la Iglesia y del Estado. Las dos entidades han salido descalabradas" ${ }^{\prime 73}$. Critica esa posición La Libertad y al día siguiente continúa censurando el posicionamiento de El País por culpar al Gobierno tanto de lo de Calahorra como de lo de Barcelona, una forma fácil a su juicio de hacer oposición y de echarle la culpa, según sus palabras, hasta del diluvio universal ${ }^{74}$. En La Libertad de 13 de junio se recoge la manifestación celebrada en Santo Domingo de La Calzada en apoyo a Calahorra, en la que se oyeron consignas y gritos de ¡Abajo Logroño!, ¡Viva Burgos!, ¡Viva la catedral!, ¡Viva el obispo de Calahorra!, ¡Viva La Calzada¡ y ¡Vivan las autoridades dimitentes! ${ }^{75}$.

Lo ocurrido en Calahorra aquellos días de junio de 1892 no puede considerarse, como vemos, un mero conflicto localista y provinciano sino que se había convertido en un problema político que comprometía tanto al partido de Cánovas como al de Sagasta según consta en los diarios de sesiones de la denominada Legislatura de $1891^{76}$ y que se insertaba en el malestar ciudadano que caracterizó el final del siglo XIX en España. La prensa ya tenía entonces un papel relevante en la vida cotidiana y es también reseñable que la preocupación, que tanto había indignado a los calagurritanos, recalase con rapidez en el Congreso ya que si los sucesos habían comenzado la noche del martes 7 de junio, el Diario de las Sesiones de Cortes de 10 de junio de 1892 recoge las preguntas formuladas al Ministro de Gracia y Justicia por los diputados Barrio y Mier, así como, por Tirso Rodrigáñez. El primero en interpelar en el Congrego al fue Barrio y Mier que en clara referencia a Sagasta preguntó con interés por "la traslación intentada y, no sé si

71. La Libertad, diario publicado en Madrid y dirigido por Javier Betegó, sustituyó en 1890 a La Monarquía, nacido a su vez en 1887.

72. La Libertad, $n^{\circ} 642,10$ de junio de 1892 , p. 1. No obstante la primera noticia del motín la publica el 9 de junio de $1892, n^{\circ} 641$, p. 3.

73. La Libertad, $\mathrm{n}^{\circ} 643$ de 11 de junio de 1892, p. 1.

74. La Libertad, $n^{\circ} 644$ de 12 de junio de 1892, p. 1.

75. La Libertad, $\mathrm{n}^{\circ} 645$ de 13 de junio de 1892, p. 1.

76. Legislatura de 1891, la duración de esta legislatura va desde el 2 de marzo de 1891 al 5 de enero de 1893. 
definitivamente acordada, de la Silla episcopal de la antigua e ilustre ciudad de Calahorra a la población de Logroño, capital de la provincia civil del mismo nombre y cuna de algún hombre político de gran importancia en el juego de nuestros partidos militantes" ${ }^{\prime 77}$. Por su parte el diputado Rodrigáñez resaltó lo que consideraba imprudencias gubernamentales y no en la intervención del gobernador al que, a su juicio, el ministro estaba echando la culpa de lo sucedido, mientras que el citado gobernador, "está en Calahorra siendo víctima de unos y de otros". La acusación de imprudencia y de dejación de funciones y falta de autoridad al haber resignado "el mando la autoridad civil en manos de la militar, resulta también que se ha hecho dejación de facultades en manos de la autoridad eclesiástica"78.

\section{El segundo motín: entre la sátira y la internacionalización del conflicto}

No es menos importante a la hora de juzgar el alcance del motín de Calahorra que además de haber acaparado el interés de la prensa española y haber sido ocasión de varias discusiones en el Congreso de los Diputados lo fuera también por la prensa extranjera. A mi juicio este hecho se produce por la peculiaridad que las causas que lo produjeron tenían respecto a los motines o revueltas que además había por todo el país. Con un gobierno conservador y extremadamente católico como el de Cánovas, como había expresado el diario El País, surgía un conflicto de índole religiosa que unía a los detractores por encima de los colores políticos. Es posible que fuera esa originalidad la que convirtió el conflicto calagurritano en noticia internacional y que, en concreto, fuera The New York Times el que con igual inmediatez que el resto de la prensa española diera el 11 de junio de 1892 a sus lectores las noticias sobre la revuelta popular que había tenido lugar en Calahorra, en la vieja Castilla, con ocasión del posible traslado de la Silla Episcopal de una de las diócesis más antiguas de España. Un debate que indudablemente sorprendería a los neoyorquinos por su peculiaridad respecto de otros conflictos sociales que también ellos conocían, pues en EE.UU. se vivían momentos de descontento por los bajos salarios y la insalubridad de las condiciones laborales, eran tiempos de transformación industrial, de inmigración y de conflictividad propia de momentos de cambio pero quizá no tanto de disputas religiosas.

El titular de The New York Times decía "CHURCH RIOT AT CALAHORRA. CANON RUIZ ATTACKED WITH CLUBS AND STONES BY THE MOB. (MANIFESTACION ECLESIASTICA EN CALAHORRA. CANÓNIGO RUIZ ATACADO POR LA MULTITUD CON PALOS Y PIEDRAS) ${ }^{79}$.

77. Todo lo referido a esta discusión parlamentaria ha sido tomado de Diario de las Sesiones de Cortes, n 220, 10-VI-1892, pp. 6704-6709.

78. Diario de las Sesiones de Cortes, no 220, 10-VI-1892, pp. 6704-6707.

79. The New York Times, 11 de junio de 1892. Texto completo de la noticia publicada: CHURCH RIOT AT CALAHORRA. CANON RUIZ ATTACKED WITH CLUBS AND STONES BY THE MOB. 


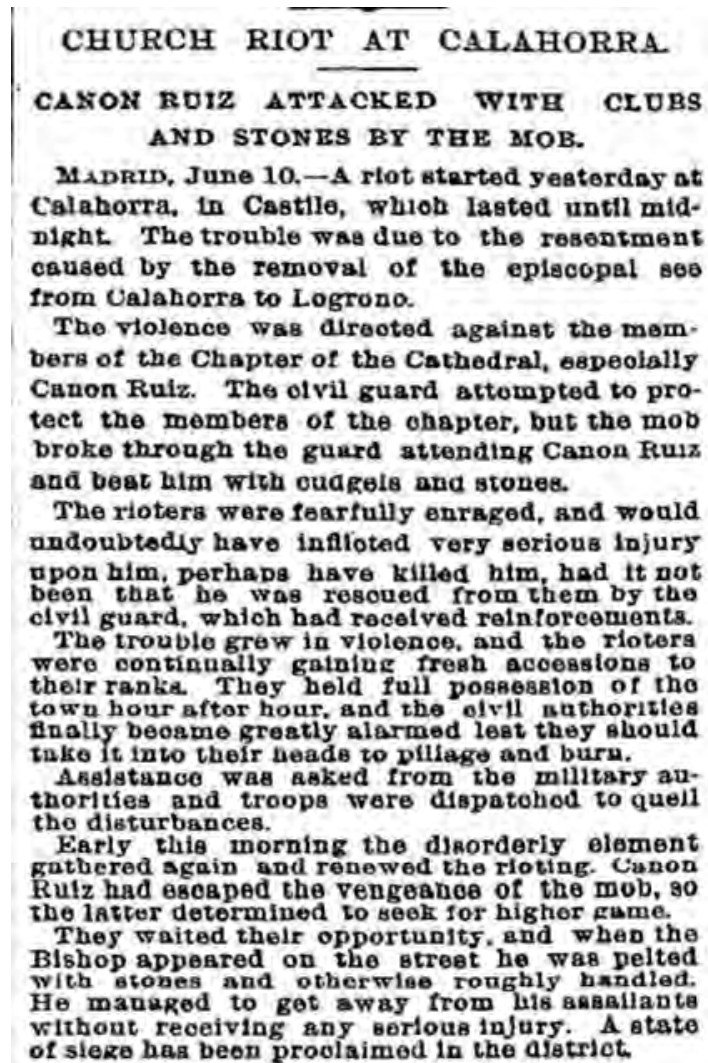

Lám. 4. Crónica publicada en The New York Times el 11 de junio de 1892.

Madrid, june 10.- A riot started yesterday at Calahorra, in Castille, wjich lasted until midnight. The trouble was due to the resentment caused by the removal of the Episcopal see from Calahorra to Logroño. The violence was directed against the members of the chapter, but the mob broke through the guard attending Canon Ruiz and beat him with cudgels and stones.

The rioters were fearfully enraged, and would undoubtedly have inflicted very serious injury upon him, perhaps have killed him, had it not been that he was rescued from them by the civil guard, which had received reinforcements.

The trouble grew in violence, and the rioters were continually gaining fresh accessions to their ranks. They held full possession of the town hour after hour, and the civil authorities finally became greatly alarmed lest they should take it into their heads to pillage and burn.

Assistance was asked from the military authorities and troops were dispatched to quell the disturbances.

Early this morning the disorderly element gathered again and renewed the rioting, Canon Ruiz had escaped the vengeance of the mob, so the latter determined to seek for higher game.

The waited their opportunity, and when the Bishop appeared on the street he was pelted with stones and otherwise roughly handled. He managed to get away from his assailants without receiving any serious injury. A state of siege has been proclaimed in the district. 
La crónica relataba, con cierto detalle lo ocurrido y, salvo la confusión de Ilamar obispo al Vicario Capitular, Santiago Palacios, que en realidad ejercía las funciones de un Prelado, la noticia difundida por el periódico neoyorquino no dista mucha de todo lo relatado hasta el momento, en relación a lo ocurrido:

Una huelga, (o revuelta) se inició ayer en Calahorra, Castilla, que ha durado hasta medianoche. El altercado fue debido al resentimiento originado por el traslado de la sede episcopal de Calahorra a Logroño. La violencia se dirigió contra los miembros de la congregación, pero la multitud se abrió paso ante la guardia del Canónigo Ruiz, golpeándolo con porras y piedras. Los manifestantes estaban violentamente enfurecidos, y sin duda pudieron haberle provocado lesiones muy serias, incluso causándole la muerte, de no haber sido porque fue rescatado por la guardia civil, que había recibido refuerzos. La situación se volvió más violenta y los manifestantes ganaban terreno continuamente. Iban tomando posesión de la ciudad a medida que pasaban las horas, y las autoridades civiles aumentaron su alerta por precaución a que tomaran posesión de sus puestos de mando. Se solicitaron refuerzos a las autoridades militares y se enviaron tropas para sofocar los disturbios. A primera hora de esta mañana los manifestantes se volvieron a congregar y reanudaron los desórdenes. El canónigo Ruiz había escapado a la venganza de la multitud, buscando ésta un mayor ajustamiento. Esperaron su oportunidad y cuando el Obispo hizo su aparición en la calle, fue apedreado y duramente increpado. Logró escapar de sus agresores sin que le causaran ninguna lesión grave. En el lugar se ha proclamado el estado de sitio $^{80}$.

Probablemente los neoyorquinos no sabían que pese a la originalidad de la protesta calagurritana los conflictos se extendían entonces por toda España. Abundando en este aspecto y de no menos interés, para analizar el problema finisecular en España, es el humor con que siguieron la noticia suplementos como la revista Blanco y Negro, de $A B C$ que en su número de 19 de junio, en la sección Un poco de todo escribía la siguiente coplilla:

Huelga en Valladolid.

Huelgas, tiros, pedradas y atropellos en Cataluña.

Pedradas, tiros, puñaladas y otros excesos en Calahorra.

Un par de suicidios al día.

Un crimen espantoso a turno diario.

En fin que sólo nos falta

Poner en los Pirineos

Un letrerito que diga

"Por aquí se entra en el cielo" ${ }^{81}$

80. The New York Times, 11 de junio de 1892.

81. Blanco y Negro, $\mathrm{n}^{\circ} 59$ de 19 de junio de 1892, p. 1. 
El aire burlesco y de chirigota entrañaba en estos versos y en otros semejantes una crítica evidente al sistema de la restauración, el Gobierno de Cánovas atravesaba momentos de dificultad, en las discusiones del Congreso se hablaba de subidas de impuestos y, como hemos visto en la prensa, de cómo frenar el descontento social que se multiplicaba por todos los rincones como apunta la copla anterior, el mes de junio sería un mes absolutamente desfavorable para un Gobierno que languidecía por momentos y que se encaminaba a su final, así lo señala Blanco y Negro, en tono de letrilla satírica:

Por inspiraciones, quizás del Infierno,

El mes inmediato pasado de Junio,

Para el aturdido y enclenque Gobierno,

Ha sido de horrible, constante infortunio,

De estar dando voces, en un jay! Eterno.

Conflictos y quejas ha habido a montones

En el Municipio y en la mayoría;

Ha habido derrotas en las votaciones,

$Y$ apenas pasamos tranquilos un día

Sin nuevos disgustos y nuevas cuestiones.

Ha habido en Linares (no Rivas) "camorra»;

Siguió en Barcelona creciendo el «jaleo»;

Terrible conflicto surgió en Calahorra,

Y aquí otro, más grave, se puso tan feo,

Qué a poco al Gobierno no hay quien lo socorra ${ }^{82}$.

Si el mes de junio había sido complicado el siguiente no lo sería menos ni en España ni en Calahorra. El 26 de junio en la localidad riojabajeña se reunió la Corporación municipal en una sesión a puerta cerrada a consecuencia de los rumores que circulaban sobre la posible alteración del orden público "el día 29 del actual día que debe tener lugar la anunciada subasta del arrendamiento de la cobranza del impuesto de consumos". Esa era la causa por la que el alcalde había conferenciado con el jefe de la fuerza militar y capitán de la Guardia $\mathrm{Civi}^{83}$. En esta ocasión las autoridades decidieron que nada pudiera sorprenderles, ahora ya no se trataba sólo de las tradiciones de la ciudad sino de los impuestos que minaban la capacidad de subsistencia de una ciudad mayoritariamente dedicada a la agricultura en explotaciones familiares minifundistas y

82. Blanco y Negro, $n^{\circ} 61$ de 3 de julio de 1892, p. 13. Junto a esa letrilla se publicaba esta otra:

"Al Obispo de Calahorra lo quieren desobispocalagurritanizar;

El desobispocalagurritanizados que lo desobispocalagurritanizare, buen desobispocalagurritaniador será".

Firma un calagurritano.

83. AMC, Actas Municipales, 26 de junio de 1892, sig. 141/3 Cod. 1.3.0.7. 
escasamente rentables, lo que hacía prácticamente imposible la subsistencia. Con especial cautela, se acordó suspender la subasta y sustituir el gravamen al trigo y harinas, en la parte municipal y trasladarla a otro consumo para compensar la pérdida de ingresos pero consideraban que aliviaban el de un producto de primera necesidad en la época como era el pan ${ }^{84}$. Como recoge La Rioja Católica en su número de 30 de junio, el remate de la subasta quedó suspendido y la simple presencia de las tropas controló la situación sin problemas ni alteraciones de ningún tipo ${ }^{85}$. En la ciudad todo aparentaba que la situación estaba bajo control pero los vecinos estaban demasiado inquietos y cuando las tropas hubieron salido de Calahorra el motín comenzó de nuevo. Los calagurritanos el 3 de julio se echaron de nuevo a la calle a elevar su protesta contra "los consumos". Los hechos comenzaron ese día a partir de las tres de la tarde cuando grupos de manifestantes se concentraron en la plaza del Raso y se dirigieron a la casa del Alcalde. La petición que le formularon fue la puesta en libertad de los detenidos con motivo de los sucesos de primeros de junio y cuando éste les explicó que el asunto estaba en manos del Juez, se dirigieron a casa del segundo que, a su vez, les indicó que el tema estaba pendiente de resolver por la Audiencia Provincial. A partir de ese momento, según recoge La Rioja, comenzaron a apedrear casas de concejales, se incendiaron tres casas, las "turbas sitiaron al telegrafista" $y$ "se dice que (las turbas) penetraron en la cárcel poniendo en libertad a los presos". Por las autoridades se dieron órdenes para que en el tren de las cinco de la madrugada salieran un regimiento de caballería y un batallón de infantería acompañados del Gobernador Militar, el comandante de la Guardia Civil y el Fiscal de la Audiencia, mientras se preparaba para partir un regimiento de Ingenieros. Parece ser que a las tres de la madrugada se había disuelto el motín. Las tropas Ilegaron posteriormente y se prepararon para evitar otros disturbios. La Rioja, bajo el titular "Motines en Madrid", cuenta que también en la capital de la corte se había sofocado otro motín y que podía darse por concluido el conflicto ocasionado por los vendedores ambulantes y los de las plazuelas con motivo de los nuevos impuestos municipales ${ }^{86}$.

Al día siguiente La Rioja explicaba que la causa del motín había sido esta vez "el odioso impuesto de consumos, ese tributo que produce más disgustos que pesetas, que cuenta con escasos e insignificantes partidarios y al cual, sin embargo, ningún gobierno se atreve a desterrar". No obstante el periódico consideraba que una de las causas de lo ocurrido era "haberse acostumbrado el pueblo a ser rey y señor de vidas y haciendas, al ver como se amotinaba y cometía delitos sin que sobre ellos se notase un castigo apropiado a la falta" ${ }^{\prime 87}$.

84. AMC, Actas Municipales, 26 de junio de 1892, sig. 141/3 Cod. 1.3.0.7.

85. La Rioja Católica, n ${ }^{\circ} 26$ de 30 de junio de 1892, pp. 8 y 9.

86. Datos recogidos de La Rioja, n 1.033 de 4 de julio de 1892, p. 1.

87. La Rioja, no 1.034 de 4 de julio de 1892. 
El 5 de julio, al igual que en el motín de junio, la Cámara de Diputados fue escenario de un arduo debate sobre los acontecimientos ocurridos en Calahorra como protesta contra el impuesto los consumos. La discusión, protagonizada por el diputado Tirso Rodrigáñez y el ministro de la Gobernación en ese momento, Fernández Villaverde, se centró en la oportunidad del proceder del Gobierno y en la proporcionalidad o no de las fuerzas utilizadas para sofocar el segundo motín en menos de un mes $^{88}$. En esta ocasión, los ciudadanos de otras poblaciones riojanas como Rincón de Soto, Autol, Alfaro, Arnedo, etc. también invadieron las calles protestando por el impuesto de consumos. El análisis de lo que estaba ocurriendo en la provincia Ileva a La Rioja a realizar afirmaciones contundentes bajo el titular "Síntomas graves" donde explicaba que

Pueden y deben los pueblos protestar contra aquellos impuestos que no les gusten; pueden elegir diputados que les ofrezcan combatirlo, pueden llevar al Municipio hombres que sepan suavizar los inconvenientes y hasta variar la forma de exacción; lo que no pueden ni deben es acudir a motines hoy y doblegarse mañana a la voluntad del cacique ${ }^{89}$.

La recomendación del periódico liberal es la de utilizar la democracia para cambiar a los gobernantes por métodos pacíficos huyendo de la complacencia a los caciques, pero como es conocido y se ha señalado el sistema electoral tenía entonces deficiencias que derivaron en un cansancio del sistema empleado en el período de la Restauración. Calahorra no fue un caso aislado ya que la situación social de fin de siglo en toda España era enormemente problemática como consecuencia del deterioro continuo de la situación social de los españoles.

No obstante en Calahorra el temor de las clases acomodadas y de algunos clérigos influidos por lo ocurrido en el mes de junio y aunque la revuelta nada tenía que ver ahora con el traslado de la Silla de la que algunos, como la familia del arzobispo de Valladolid Antonio María Cascajares, conocido partidario de la causa popular en este aspecto, decidieron salir por un tiempo de la ciudad. En ellos primó el miedo a represalias relacionadas con su desahogada situación económica que en aquellos momentos era proclive a ser objeto de las iras de quienes no alcanzaban siquiera a comprar el pan. El malestar social era evidente y se anunciaba también "una sublevación contra los propietarios para no pagar las rentas y que empieza el desfile de personas temerosas de lo que pueda suceder ${ }^{\prime \prime 90}$. Lógicamente sólo los más ricos podían partir, los propietarios de tierras arrendadas y de una situación social acomodada, pues no se puede

88. Diario de las Sesiones de Cortes, Biblioteca del Congreso de los Diputados, $\mathrm{n}^{\circ} 239,5$ de julio de 1892, pp. 7574-7577. Como se ha explicado en nota 79, sólo dos personas fueron detenidas y posteriormente juzgadas por los sucesos de junio.

89. La Rioja, $\mathrm{n}^{\circ} 1.035$ de 6 de julio de 1892, p. 1.

90. La Rioja, $\mathrm{n}^{\circ} 1.035$ de 6 de julio de 1892, p. 1. 
olvidar como bien señala López Rodríguez que la estructura de la propiedad en Calahorra era de un extremado minifundio y el nivel de analfabetismo superaba con creces la media de la provincia ${ }^{91}$. Entre los que salieron de Calahorra por el temor de los sucesos de aquellos días, se encontraba también el rico banquero D. Ceferino Moreno ${ }^{92}$. Asimismo, varios concejales pidieron permiso para ausentarse unos meses por causa de sus negocios y algunos canónigos pidieron el traslado a otras diócesis aunque tardaron años en obtenerlo ${ }^{93}$.

El clamor de lo acontecido también llegó a la prensa nacional unido en la información de La Vanguardia a conflictos en Madrid y Barcelona, aunque apuntaba que pese a todo no había sido necesario declarar el estado de sitio aunque la ciudad seguía tomada por tres regimientos "para apaciguar los ánimos" ${ }^{\prime 94}$. La Correspondencia de España resalta que con la presentación de la tropa mandada por el General Moltó, ha quedado restablecido el orden en Calahorra. Señala, no obstante, que hay quien considera exagerado el envío de tres regimientos a un pueblo de "tan escasa población e importancia". Informa también de las numerosas detenciones practicadas y de que el diputado Rodrigañez acusa de imprevisión al ministro de la Gobernación en las Cortes y pide una guarnición permanente en la ciudad ${ }^{95}$.

La Libertad, el 6 de julio, también da cumplida cuenta a sus lectores de lo ocurrido $^{96}$. Ese mismo día que The New York Times, hacía lo propio con los suyos transmitiéndoles que un nuevo motín había estallado en España y, en concreto, en Calahorra, una ciudad de la que ya habían tenido noticia los neoyorkinos hacía sólo un mes ${ }^{97}$ : ANOTHER RIOT IN SPAIN. THE PRISON AT

91. A este respecto se dan datos interesantes en López Rodríguez, P., Calahorra, Levítica y Liberal..., pp. 15-27.

92. Gil Andrés, C., Protesta popular y orden social..., p. 162, él lo toma de La Época, no 14.306 de 7 de julio de 1892 .

93. AMC, Sig. 3.042/3-15 Cod. 4.2.2.9.

94. La Vanguardia, $\mathrm{n}^{\circ} 3.289,6$ de julio de 1892, p. 5.

95. La Correspondencia de España, no 12.509 de 6 de julio de 1892, p. 1. En la información del $n^{\circ} 12.511$ de 8 de julio de 1892, p. 1, señala que queda una fuerza del ejército en Calahorra.

96. La Libertad, $\mathrm{n}^{\circ} 665$ de 6 de julio de 1892, p. 1.

97. The New York Times, 6 de Julio de 1892. Texto completo publicado: ANOTHER RIOT IN SPAIN. THE PRISON AT CALAHORRA STORMED AND DWELLINGS BURNED

Madrid, July 5.- A riotous mob to-day attempted to force the prison at Calahorra, in Old Castle, with the object of rescuing the convicts there confined. As soon as the prison authorities learned the intention of the mob, they summoned military assistance to defend the prison. Several regiments of cavalry and infantry were ordered to the prison to quell the disturbance. Martial law has been proclaimed in the town. The mob, when it reached the prison, demanded the release of the men who had been imprisoned for rioting. When their demand was refused some of the rioters beset the barraks to prevent the guard coming out, while others stoned and threatened to burn the houses of the Municipal Councilors. The troops that were sent for came from Logroño, the capital of the province, and they soon quelled the rioting. Before they arrived, 
CALAHORRA STORMED AND DWELLINGS BURNED. Como vemos el titular de The New York Times explicaba que una nueva revuelta había estallado en Calahorra y que para sofocarla había sido necesario pedir refuerzos a la cabaIlería e infantería ya que la multitud había asaltado la cárcel con el objeto de liberar a algunos presos que habían sido encarcelados. Aunque no lo cita ya sabemos que se refiere a los detenidos con motivo del anterior motín de junio. El periódico neoyorquino narra cómo, previamente a que las tropas sofocaran la revuelta, los enfurecidos manifestantes había quemado las casas de tres concejales. Describe también como, pese a haber sido sofocado el tumulto, los temores persistían lo que había propiciado que algunas familias ricas del lugar hubieran partido de la ciudad hasta que todo volviera a la situación de normalidad.

Esta vez el eco internacional del motín calagurritano anota una nueva marca, según el diario La Libertad el diario francés Le Temps, se convierte en París en altavoz de "los desórdenes ocurridos últimamente en Madrid y Calahorra, y del banquete carlista en Guernica" según La Libertad el francés Le Temps "pretende que estos hechos revelan la situación algo que viene a contrariar un poco el acostumbrado optimismo de los hombres de Estado españoles y extranjeros ${ }^{\prime \prime 98}$. Como resultado de este nuevo motín fueron detenidos por la jurisdicción de Guerra nueve personas y por la ordinaria superaba los treinta ${ }^{99}$.

however, the houses of three of the Municipal Councillors were burned, as was also a building devoted to the use of the officials charged with the collection of the oetroitax (octroitax? No se lee bien en la foto del periódico). The windows of several houses were smashed. The population of Calahorra are greatly excited, and fears are entertained that there will be further trouble. Some of the wealthy families of the place are leaving until affairs resume their normal aspect. (OTRO MOTÍN EN ESPAÑA. LA CÁRCEL DE CALAHORRA ASALTADA Y ALGUNAS VIVIENDAS QUEMADAS. Madrid, 5 de julio. Una muchedumbre descontrolada ha intentado forzar hoy la cárcel de Calahorra, en el antiguo castillo, con el propósito de rescatar a los reclusos allí confinados. En cuanto las autoridades se enteraron de las intenciones de la muchedumbre, pidieron asistencia militar para defender la cárcel y varios regimientos de caballería e infantería fueron enviados al lugar para acabar con los disturbios. Además, se ha declarado la ley marcial en el pueblo. Cuando la multitud llegó a la cárcel, pidió que se liberase a los hombres que habían sido encarcelados por los tumultos. Al denegárseles la petición, algunos de los amotinados comenzaron a hostigar los barracones para evitar que la guardia saliera, mientras que otros tiraban piedras y amenazaban con quemar las casas de los consejeros municipales. Las tropas enviadas desde Logroño, capital de la provincia, pronto acabaron con los disturbios pero, antes de que llegaran, ya habían ardido las casas de tres consejeros municipales y también el edificio de uso funcionarial dedicado a la recaudación de impuestos. Las ventanas de varias casas han sido destrozadas y la población de Calahorra está enormemente exaltada, por lo que se teme que habrá más problemas. Algunas de las familias más acaudaladas del lugar han comenzado a marcharse hasta que las cosas vuelvan a la normalidad).

98. La Libertad, $\mathrm{n}^{\circ} 666$ de 7 de julio de 1892, p. 2.

99. La Libertad, $\mathrm{n}^{\circ} 667$ de 8 de julio de 1892, p. 2. 


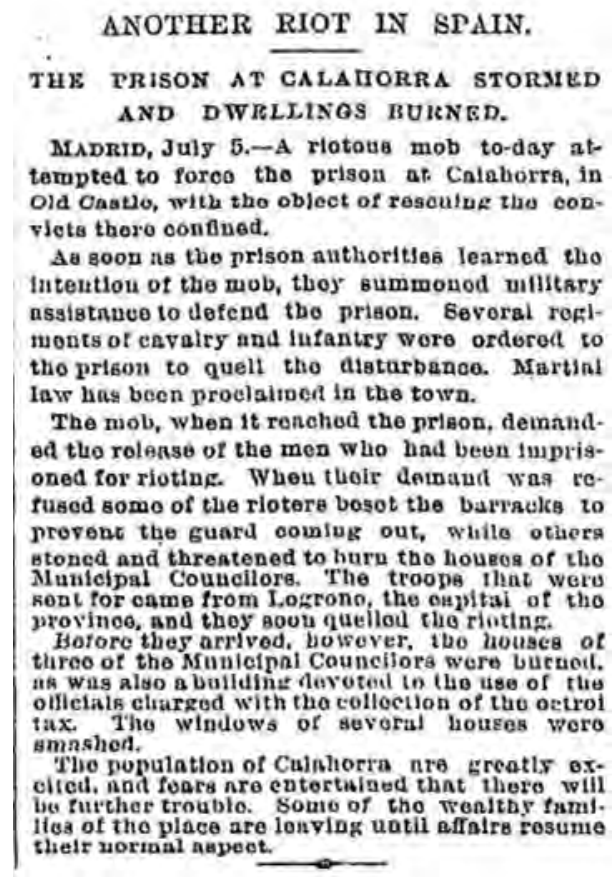

Lám. 5. The New York Times, 6 de julio de 1892.

Efectivamente como señala el parisino Le Temps los hechos no eran aislados, toda España estaba insuflada de descontentos y los mismos eran fuente de inspiración satírica, un género muy propio de la época. Así Blanco y Negro, con anterioridad en Un poco de todo, ya había dirigido claras invectivas al deterioro de la situación social y al desgaste del gobierno conservador:

"La vida es imposible

Con los conservadores;

Pero ¿cuándo se marchan

Estos buenos señores?

Apenas sin conflicto

Transcurre una semana:

Hay por la tarde huelga,

Motín por la mañana;... ${ }^{100}$

100. Blanco y Negro, $\mathrm{n}^{\circ} 62$ de 10 de julio de 1892, p. 15. 
Por si fuera poca la soflama, la misma revista en el resumen del mes de julio incluía dos supuestas cartas de intercambiadas entre "el perro del hortelano" y "el perro de D. Antonio (Cánovas)". En la respuesta del perro de D. Antonio (Cánovas) al perro del hortelano, puede leerse el siguiente párrafo en relación a la intervención del Presidente del Gobierno en las Cortes con motivo de los recientes y múltiples motines:

Yo creo que mi amo y señor al decir lo que dijo en el Senado, sólo trató de hacer una figura retórica o una imitación de lo del perro de Alcibiades -el perro de Arquímedes, que dice el general Martínez- porque así como aquel ilustre ateniense cortó la cola a su perro para que la atención pública, fijándose en éste, le dejará tranquilo, así don Antonio sacóme a relucir para que se volvieran a mí todas las miradas que estaban en él fijas. ¡Y gracias que no le se le ocurrió cortarme la cola! Pensaría quizás, en sus altos juicios, que a lo mejor será cortársela a la cuestión social, que esa sí que «trae cola».

No te negaré que, al pronto, me engrió el ser considerado capaz de hacer una hombrada, o una perrada, que en este caso venía a ser lo mismo, y que me halagó la idea de hacer un viaje redondo por España, si a mi amo le daba la ocurrencia de enviarme a concluir motines. ¡Porque cuidado si los ha habido en el dichoso mes de Julio! En Barcelona, en Garrucha, en Calahorra, en Calasparra, en Lubron, en Lorca, en Tabernas - pauperunque tabernas, como dice el citado Fabié,- en Pontevedra, en Almería, en Murcia, en... ¡qué sé yo! ${ }^{101}$

No es de extrañar que El Motín, revista satírica por excelencia, publicara aquellos días del verano de 1892 una enorme viñeta en la que en el centro un Cánovas, custodiado por un perro cancerbero, se preguntaba: ¿adónde acudo? y a su alrededor imágenes de revueltas populares en Pontevedra, Almería, Santander y Calahorra ${ }^{102}$.

101. Blanco y Negro, no 65 de julio de 1892, pp. 9 y 10 y p. 31. El perro de don Antonio, es el de Antonio Cánovas y firma como León ya que según él "en las monedas que llaman del perro lo que figura es un león. Pues bien, para pintar la época a la que hemos llegado, basta fijarse en esto: Al león de España le Ilaman perro: al perro de Cánovas le Ilaman León". Junto a estas cartas en el mismo número puede leerse: "Mire usted; algo hemos sacado en limpio con el motín del otro día. El saber que el Sr. Cánovas tiene un perro para soltarle a los amotinados que vayan a su casa. Poco a poco va a desfilar ante las Cortes toda la servidumbre de D. Antonio. Ya conocemos a Ramón, al perro... Estoy deseando que salgan en la discusión la cocinera, el loro...".

102. El Motín, $\mathrm{n}^{\circ} 32$ de 8 de agosto de 1892, pp. 2-3. 


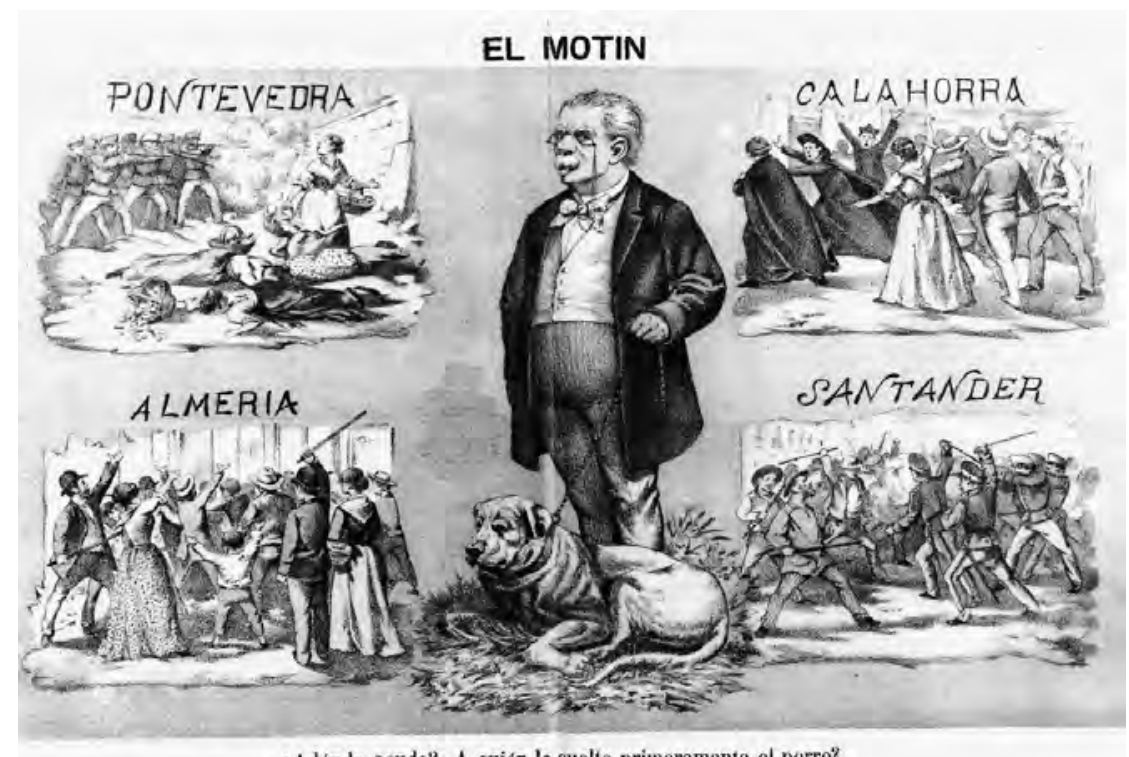

¿Adónde acudo? ¿A quién le suelto primeramente el perro?

Lám. 6. El Motín, no 32 de 8 de agosto de 1892.

No cabe duda de que el gobierno de Cánovas estaba, a lo largo del verano de 1892, en parámetros mínimos de credibilidad, pero siendo justos, hay que señalar que lo que estaba bajo mínimos en el aprecio de la población era el propio sistema de la Restauración. El Motín apuntaba esta reflexión poco antes de la dimisión del presidente Cánovas:

Que la raza de los Quijotes, propicia siempre a sacrificarse por el bien ajeno, va desapareciendo poco a poco absobida (sic) por la de los Sanchos que van a su negocio.

Y, en fin, que en el orden moral, como en el material, la restauración va acabando con todo lo que eleva, dignifica y salva, a ciencia y paciencia de los jefes republicanos, que se han entretenido durante ese tiempo en recriminarse, dividir las masas y discutir miserias y pequeñeces a pretexto de mantener en toda su pureza la integridad de los principios respectivos.

Y siendo esto así, ¿habrá quien extrañe que culpe a los actuales jefes de la situación actual de España, casi tanto como a Cánovas y a Sagasta? ${ }^{103}$.

103. El Motín, 31 de octubre de 1891, pp. 1-4. 


\section{Conclusión}

Podemos decir, a modo de breve conclusión, que 1892 será un año crucial en la historia de Calahorra que había sufrido en su propia experiencia las tensiones de un Concordato de conveniencia entre la Iglesia y el Estado, una norma plagada de contradicciones y de confusiones intercaladas entre ambos poderes que repartían beneficios y canonjías turnándose para ello como lo hacían Cánovas y Sagasta en el gobierno. Puede que ésta sea la peculiaridad de los motines de junio y julio en la capital de la diócesis de Calahorra y La Calzada, pero lo que también vemos de forma evidente, es que Calahorra estaba enferma del mismo mal endémico que el resto de España. La enfermedad no es otra que la que se produce como consecuencia del hambre, la desigualdad y la decepción política de un sistema político que languidecía pese a que su pervivencia quedaría asegurada todavía durante años por la conjunción de intereses de los más poderosos. Por eso, los motines como el de Calahorra tuvieron en ocasiones un aire épico entre sus convecinos que se negaron a identificar a los cabecillas de la revuelta, una muestra más de la solidaridad ante la protesta de las propias fuerzas de orden público ${ }^{104}$. Por su parte la prensa, como hemos visto contó lo sucedido y nos ha permitido reconstruir la repercusión de un conflicto local más allá del limitado ámbito en que se produjo.

104. Finalmente sólo 2 personas fueron acusadas por el motín de junio: "Ante la Audiencia de Logroño se ha visto la causa instruida con motivo del motín de Calahorra, en el banco se sentaron 2 personas que apalearon a un inspector de policía, contra los cuales pide el fiscal 2 y 7 años de prisión mayor y multa, la defensa pide la absolución por considerarlos inocentes" . La Vanguardia, $\mathrm{n}^{\circ} 3.388,14$ de octubre de 1892, p. 5. 